\title{
New national and regional bryophyte records, 44
}

ARTICLE in JOURNAL OF BRYOLOGY A APRIL 2015

Impact Factor: $1.65 \cdot$ DOI: 10.1179/1743282015Y.0000000014

29 AUTHORS, INCLUDING:

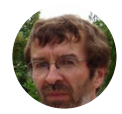

Marc Lebouvier

French National Centre for Scientific Resea. .

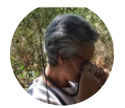

Cecília Sérgio

University of Lisbon

100 PUBLICATIONS 571 CITATIONS

162 PUBLICATIONS 934 CITATIONS

SEE PROFILE

SEE PROFILE

\section{César Garcia}

National Museum of Natural History and Sc. .

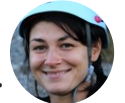

Roxana Ion

Institute of Biology Bucharest, Romanian A...

57 PUBLICATIONS 247 CITATIONS

5 PUBLICATIONS 0 CITATIONS

SEE PROFILE

SEE PROFILE 


\title{
New national and regional bryophyte
} records, 44

\author{
L. T. Ellis ${ }^{1}$, A. Alegro², V. Šegota ${ }^{2}$, V. A. Bakalin ${ }^{3,4}$, R. Barone ${ }^{5}$, \\ E. A. Borovichev ${ }^{6,7}$, V. Hugonnot ${ }^{8}$, M. Lebouvier ${ }^{9}$, M. Nobis ${ }^{10}$, A. Nowak $^{11}$, \\ R. Ochyra ${ }^{12}$, B. Papp ${ }^{13}$, E. Szurdoki ${ }^{13}$, R. Piwowarczyk ${ }^{14}$, V. Plášek ${ }^{15}$, L. Č́hal ${ }^{15}$, \\ Z.-J. Ren $^{16}$, M. S. Sabovljević ${ }^{17}$, C. Sérgio ${ }^{18}$, C. A. Garcia ${ }^{18}$, I. Melo ${ }^{18}$, \\ J. Sawickii ${ }^{15,19}$, A. Stebel ${ }^{20}$, S. Ştefănuţ ${ }^{21}$, R. Ion $^{21}$, A. Manole ${ }^{21}$, I. Tziortzis ${ }^{22}$, \\ Y. Xiong ${ }^{23}$, Z.-T. Zhao ${ }^{24}$
}

${ }^{1}$ The Natural History Museum, London, UK, ${ }^{2}$ Department of Biology, University of Zagreb, Croatia, ${ }^{3}$ Botanical Garden-Institute, Vladivostok, Russia, ${ }^{4}$ Institute of Biology and Soil Science, Vladivostok, Russia, ${ }^{5}$ Dipartimento di Scienze e Tecnologie Biologiche, Chimiche e Farmaceutiche - Sezione di Botanica ed Ecologia Vegetale, Università di Palermo, Palermo, Italy, ${ }^{6}$ Polar-Alpine Botanical Garden-Institute of the Kola Science Center of RAS, Kirovsk, Murmansk Province, Russia, ${ }^{7}$ Institute of Industrial Ecology Problems of the North of the Kola Science Center of RAS, Apatity, Murmansk Province, Russia, ${ }^{8}$ Conservatoire Botanique National du Massif Central, le Bourg, Lafayette, France, ${ }^{9} \mathrm{CNRS}$ UMR 6553, Université de Rennes 1, France, ${ }^{10}$ Jagiellonian University in Kraków, Poland, ${ }^{11}$ University of Opole, Poland, ${ }^{12}$ Laboratory of Bryology, Institute of Botany, Polish Academy of Sciences, Poland, ${ }^{13}$ Botanical Department, Hungarian Natural History Museum, Budapest, Hungary, ${ }^{14}$ Department of Botany, Institute of Biology, Jan Kochanowski University, Kielce, Poland, ${ }^{15}$ University of Ostrava, Czech Republic, ${ }^{16}$ Shandong Museum, Jinan, China, ${ }^{17}$ Institute of Botany and Botanical Garden, Faculty of Biology, University of Belgrade, Serbia, ${ }^{18}$ Universidade de Lisboa, Museu Nacional de História Natural e da Ciência, Portugal, ${ }^{19}$ University of Warmia and Mazury in Olsztyn, Poland, ${ }^{20}$ Department of Pharmaceutical Botany, Medical University of Silesia in Katowice, Sosnowiec, Poland, ${ }^{21}$ Institute of Biology Bucharest of Romanian Academy, Romania, ${ }^{22}$ Enalia Physis Environmental Research Center, Nicosia, Cyprus, ${ }^{23}$ College of Life Sciences, Guizhou University, Guiyang, China, ${ }^{24}$ Shandong Normal University, Jinan, China

1. Bucklandiella pachydictyon (Cardot) BednarekOchyra \& Ochyra

Contributor: R. Ochyra

Tristan da Cunha: (1) small patches in tuft of moss above Nellie's Hump, alt. $4500 \mathrm{ft}$ (=1375 m a.s.1.), 18 October 1955, leg. N. M. Wace T. 539 (BM); (2) alpine desert, above $5000 \mathrm{ft}$ ( $=1525 \mathrm{~m}$ a.s.1.) [associated with Bucklandiella membranacea (Mitt.) Bednarek-Ochyra \& Ochyra], 18 October 1955, leg. N. M. Wace T. $529 \&$ T. 530 (BM).

Situated in the cool-temperate zone in the middle of the South Atlantic Ocean, the small archipelago of Tristan da Cunha is an important outpost for many austral cool-adapted species of moss. They usually exhibit an amphiatlantic distribution pattern, occurring in southern South America and then re-appearing after a dramatic oceanic disjunction on subantarctic islands in the Kerguelen Biogeographical

Correspondence to: Leonard T. Ellis, Department of Life Sciences, The Natural History Museum, Cromwell Road, London SW7 5BD, UK. Email: l.ellis@nhm.ac.uk
Province in the South Indian Ocean. The most typical examples of such ranges are Ditrichum conicum (Mont.) Mitt. (Ochyra \& Lewis Smith, 1998; Blockeel et al., 2010; Ochyra \& Bednarek-Ochyra, 2013), Philonotis polymorpha (Müll.Hal.) Broth. (Ellis et al., 2013b; Bednarek-Ochyra, 2014a), Bucklandiella membranacea (Ellis et al., 2013c), B. lamprocarpa (Müll.Hal.) Bednarek-Ochyra \& Ochyra (Ochyra et al., 1988; Bednarek-Ochyra \& Ochyra, 1998, 2012a; Blockeel et al., 2007a, 2009a; BednarekOchyra, 2014b), B. orthotrichacea (Müll.Hal.) Bednarek-Ochyra \& Ochyra (Bednarek-Ochyra \& Ochyra, 2012b; Bednarek-Ochyra, 2014c), B. striatipila (Cardot) Bednarek-Ochyra \& Ochyra (Blockeel et al., 2009c; Bednarek-Ochyra \& Ochyra, 2010a, 2013; Ellis et al., 2013a), Hygrodicranum falklandicum Cardot (Blockeel et al., 2007b), and Bryum orbiculatidolium Cardot \& Broth. (Blockeel et al., 2008). This group is now increased by one distinct species, Bucklandiella pachydictyon. So far, it has been known to be widely distributed in southern South America where it is relatively frequent along 
the western coast of the continent, ranging from the Argentinean Neuquén and Chilean Cautin Provinces to Tierra de Fuego and extending to the northern maritime Antarctic (Deception Island) and subantarctic South Georgia (Bell, 1974; Ochyra et al., 2008a,b). The species subsequently recurs on the Prince Edward Islands and Îles Crozet (Blockeel et al., 2008), Îles Kerguelen (Cardot, 1916) and Heard Island (Ellis et al., 2015b), as well as on the Île Amsterdam in the warm-south-temperate zone (Ellis et al., 2015a). The present discovery of B. pachydictyon on Tristan da Cunha fills an obvious gap in the range of this species and confirms its phytogeographical status as an amphiatlantic southtemperate species.

2. Bucklandiella pacifica (Ireland \& J.R.Spence) Bednarek-Ochyra \& Ochyra

Contributor: R. Ochyra

United States of America. Idaho: Clearwater County, on rocks along Weitas Creek, $46^{\circ} 45^{\prime} 30^{\prime \prime} \mathrm{N}$ $116^{\circ} 03^{\prime} 50^{\prime \prime} \mathrm{W}$, ca $860 \mathrm{~m}$ a.s.1., in patch of Bucklandiella heterosticha (Hedw.) Bednarek-Ochyra \& Ochyra, 17 September 1950, leg. M. Nelson \& K. Wilson $815 A$ (ID).

Bucklandiella pacifica is one of the most distinctive North American species of the genus Bucklandiella Roiv.; it is characterised by its entirely unistratose laminal cells, the lack of basal marginal border, differentiated alar cells forming auriculate decurrencies, long-cylindrical capsule and prominently flaring peristome teeth. Moreover, it is the only species of the genus in this continent having consistently muticous leaves always lacking a hyaline hair point. The species was regarded as a narrow endemic of the Pacific coast of North America, ranging from southern Vancouver Island in British Columbia in the north, to central California in the south (Ochyra \& Bednarek-Ochyra, 2007a). It is widely distributed in the Pacific Coast Ranges within a relatively narrow zone, up to $200 \mathrm{~km}$ inland from the coast. Herein, the species is recorded for the first time from Idaho, where it occurs at a highly disjunct site situated about $600 \mathrm{~km}$ inland from the main part of its range in the Cascade Mountains. This is a wellknown glacial refugium, usually designated as the "Clearwater Refugium" in which many relictual mesic-adapted vascular plants (Daubenmire, 1975; Johnson \& Steele, 1978; Gavin, 2009) and mosses occur, including Bucklandiella obesa (Frisvoll) Bednarek-Ochyra \& Ochyra (Ellis et al., 2014b), Codriophorus norrisii (Bednarek-Ochyra \& Ochyra) Bednarek-Ochyra \& Ochyra (Bednarek-Ochyra \& Ochyra, 2000), Frisvollia varia (Mitt.) Sawicki, Szczecińska, Bednarek-Ochyra \& Ochyra (BednarekOchyra, 2006; Sawicki et al., 2015), as well as Dendroalsia abietina (Hook.) E.Britton, Homalothecium fulgescens (Müll.Hal.) A.Jaeger, Kindbergia oregana (Sull.) Ochyra, Leucolepis menziesii (Hook.) Steere, Neckera douglasii Hook., Oligotrichum aligerum Mitt., Plagiomnium venustum (Mitt.) T.J.Kop., Pseudobraunia californica (Lesq.) Broth. Rhizomnium glabrescens (Kindb.) T.J.Kop., and Scleropodium obtusifolium (Mitt.) Kindb. (Schofield, 1980; Vitt et al., 1988).

3. Campylopus purpureocaulis Dusén

Contributors: R. Ochyra and M. Lebouvier

Îles Kerguelen: Grande Terre, Presqu'île Bouquet de la Grye: $1.5 \mathrm{~km}$ north-west of the cemetery at Port Couvreux and $2 \mathrm{~km}$ west of Mont de la Vigie, $49^{\circ} 16^{\prime} 12.125^{\prime \prime} \mathrm{S} 69^{\circ} 40^{\prime} 04.578^{\prime \prime} \mathrm{E}$, ca $150 \mathrm{~m}$ a.s.l.; peatland with Juncus scheuchzerioides Gaudich., in the spring area of a stream running down to Port Couvreux, 20 November 2006, leg. et det. R. Ochyra 709/ 06 (with Ch. Brumbt) (KRAM).

Campylopus purpureocaulis is a wetland moss, which grows in large, compact tufts and owes its Latin name to its stems that are densely tomentose with reddish rhizoids. It is a south-temperate species with a highly disjunct geographical range that covers the North and South Islands of New Zealand (Bartlett \& Frahm, 1983), Tierra del Fuego and Western Patagonia (Frahm, 1976; Greene, 1986) and some subantarctic islands in the Kerguelen Biogeographical Province in the South Indian Ocean (Frahm, 1985, 1988). In the latter region, C. purpureocaulis has so far been recorded only from the Prince Edward Islands (van Zanten, 1971 as C. arboricola Cardot \& Dixon; Ochyra \& Hertel, 1990 [1991]) and Îles Crozet (Ellis et al., 2013c). Hence, its discovery on the Îles Kerguelen, the largest and the oldest archipelago in this province was to be expected. It has the richest moss flora of all subantarctic islands, consisting of about 135 species, many of which have been discovered during recent field studies (e.g. Blockeel et al., 2009b,c; Ellis et al., 2012a,b).

4. Cephaloziella varians (Gottsche) Steph.

Contributors: S. Ştefănuţ, R. Ion and A. Manole

Romania: Southern Carpathians: Bucegi Moun-

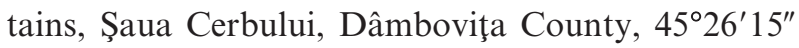
$\mathrm{N}, 25^{\circ} 27^{\prime} 08^{\prime \prime} \mathrm{E}, 2300 \mathrm{~m}$ a.s.1., on rocks, 14 June 2014, leg. R. Ion \& A. Manole s.n., det. S. Ştefănuţ (BUCA B4709).

Cephaloziella varians was collected from the alpine zone of the Bucegi Mountains, Ialomiţa Glacial Ring. The plants were growing with other bryophytes such as Clevea hyalina (Sommerf.) Lindb., Plagiochila porelloides (Torrey ex Nees) Lindenb., Scapania gymnostomophila Kaal., Distichium inclinatum (Hedw.) Bruch \& Schimp., Ditrichum gracile (Mitt.) Kuntze, Oncophorus virens (Hedw.) Brid., Syntrichia norvegica F.Weber and Tortula schimperi M.J.Cano, O.Werner \& J.Guerra. 
This is the first report of Cephaloziella varians for Romania and the south-eastern Carpathians (Ştefănuţ, 2008; Ştefănuţ \& Goia, 2012). The nearest other locality for this species is in Hungary (Ellis et al., 2014a). The conservation status of C. varians in Romania is Critically Endangered CR B1ab(ii,iii) + 2ab(ii,iii).

In Europe, C. varians has been reported from Svalbard, Iceland, Faroe Islands, Norway, Sweden, Finland, France, Switzerland, Austria, Italy, Novaya Zemlya, Franz Josef Island, Russia North (Söderström et al., 2002), Hungary (Ellis et al., 2014a) and now, Romania.

5. Codriophorus corrugatus Bednarek-Ochyra

Contributors: R. Ochyra, Z.-J. Ren and Z.-T. Zhao

China, Gansu Province: Die-bu County, Hu-Tou Shan (= tiger head mountain), $3500 \mathrm{~m}$ a.s.1., lat. $34^{\circ} 00^{\prime} \mathrm{N} 103^{\circ} 15^{\prime} \mathrm{E}$, on soil, 25 July 2006 , leg. Zuntian Zhao 200630246 (KRAM, SDNU).

Codriophorus corrugatus is readily recognised by its slender, long-acuminate leaves with a characteristic serpentine, corrugated and usually extremely wavy leaf acumen, which is acute to filiform, concolorous or subhyaline and cristate to papillose-crenulate at the apex, and short costae that extend to about mid-leaf. Despite its distinctness, it was only recently described as a species in its own right (BednarekOchyra, 2004a, 2006). It is a boreal-temperate oreophyte, penetrating weakly into the Arctic. It has a wide, typical circum-North Pacific distribution pattern, which is frequently observed in mosses and liverworts (Bednarek-Ochyra et al., 2010). The species has maximum occurrence in Japan, whilst in mainland Asia it is widely scattered, ranging from Kamchatka and Yakutia, through southern Siberia to central China. In North America, C. corrugatus is exceedingly rare and so far it has been recorded only from Alaska. In China, this species has hitherto been known from Quinghai, Shaanxi and Sichuan Provinces (Bednarek-Ochyra, 2006). Herein, it is reported from Gansu Province and this discovery extends its geographical range in central China. The material was initially named by the second contributor, with a question mark, Racomitrium anomodontoides Cardot $[\equiv$ Codriophorus anomodontoides (Cardot) Bednarek-Ochyra \& Ochyra] which is actually closely related to $C$. corrugatus (BednarekOchyra, 2006). However, it was subsequently renamed Racomitrium elongatum Frisvoll [ $[$ Niphotrichum elongatum (Frisvoll) Bednarek-Ochyra \& Ochyra] (Liu et al., 2011), although Codriophorus P.Beauv. and Niphotrichum Bednarek-Ochyra \& Ochyra are very distinctive segregates of the traditionally conceived Racomitrium Brid. (Sawicki et al., 2015). It was the first and the only report of $N$. elongatum from China and Asia, but now this record has to be deleted. Accordingly, it must still be considered a Euro-North American species (Frisvoll, 1983), which was only recently discovered in the South Island of New Zealand, where it is apparently introduced (Malcolm \& Shevock, 2012). In the moss flora of China, 22 species of the traditionally interpreted genus Racomitrium are recorded (Cao et al., 2003), but since then four taxa have been added, including Niphotrichum canescens (Hedw.) Bednarek-Ochyra \& Ochyra subsp. latifolium (C.E.O.Jensen) Bednarek-Ochyra \& Ochyra (Ellis et al., 2010), Bucklandiella shevockii BednarekOchyra \& Ochyra (Bednarek-Ochyra \& Ochyra, 2010b), as well as the aforementioned Niphotrichum elongatum and Codriophorus corrugatus. However, the former is here excluded from the flora of China and the report of $C$. acicularis (Hedw.) P.Beauv. proved to be erroneous as, correctly, the voucher material represents $C$. japonicus (Dozy \& Molk.) Bednarek-Ochyra \& Ochyra (Bednarek-Ochyra, 2004b). Thus, at present in China, the subfamily Racomitrioideae consists of 24 species and one subspecies.

6. Conocephalum salebrosum Szweykowski, Buczkowska \& Odrzykoski

Contributors: A. Stebel and R. Piwowarczyk

Georgia, Adjara, Caucasus, Meskheti Range, between Kobuleti and Chakhati, north of Kokhi: Kveda Kondidi, moist rocks along the road, on the slope of the Kintrishi river valley, within the Colchis temperate-subtropical rain forest zone, $41^{\circ} 48^{\prime} 10^{\prime \prime} \mathrm{N}$ 41 53'59"E, $92 \mathrm{~m}$ a.s.1., 5 June 2014, leg. R. Piwowarczyk s.n. (KTC, SOSN).

Conocephalum salebrosum was described relatively recently (Szweykowski et al., 2005), thus its distribution is still imperfectly known. Since that time many papers have appeared, widening its range through the Caucasus and some other areas. C. salebrosum is known from several sites in the Russian part of the mountains (Borovichev et al., 2009; Konstantinova et al., 2009a, 2009a,b; Konstantinova, 2011) and its discovery in neighbouring Georgia was to be expected. The hepatic flora of the Adjara is fairly well known (Bakalin et al., 2013), but until now $C$. salebrosum had not been reported either from this region or from Georgia as a whole.

7. Didymodon nicholsonii Culm.

Contributors: B. Papp, E. Szurdoki and M. S. Sabovljević

Serbia: Central Serbia, the Ibar valley between Ušće and Maglić, on the bank of the Ibar river and bark of Salix alba L., $43^{\circ} 33^{\prime} 27.3^{\prime \prime} \mathrm{N}, 20^{\circ} 37^{\prime} 07.0^{\prime \prime} \mathrm{E}, 320 \mathrm{~m}$ a.s.1., 26 April 2013, leg./det. Beáta Papp, Erzsébet Szurdoki and Marko S. Sabovljević s.n. (BP 188518).

Didymodon nicholsonii was recorded for the first time in Serbia, in Central Serbia in the Ibar valley 
gorge between the towns of Ušce and Maglić. It is a rare species growing in small patches on rocks and exposed roots along streams and rivers, often below flood level (Smith, 2004).

According to Sabovljević et al. (2008), D. nicholsonii had not been recorded in Serbia until now. In south-eastern Europe, it was known from Greece, and was recently reported from Montenegro (Papp et al., 2014). In the Mediterranean area, it has been recorded in Portugal, Spain, France, Italy, Turkey and Algeria (Ros et al., 2013). This species seems to show a suboceanic-submediterranean (Düll, 1984) or suboceanic-temperate (Smith, 2004) distribution. Hence, its appearance in Serbia in the Ibar gorge, strongly influenced by the Mediterranean climate, was not a surprise.

\section{Leptobryum pyriforme (Hedw.) Wilson}

\section{Contributor: R. Ochyra}

Falkland Islands, West Falkland Island: by Pilot Stream valley, Hill Cove (TC 81/89), 51 $31^{\circ} 08^{\prime \prime} \mathrm{N}$ $60^{\circ} 08^{\prime} 37^{\prime \prime} \mathrm{W}$, ca $137 \mathrm{~m}$ a.s.1., dry clay soil on a small bank among rocks, associated with Campylopus introflexus (Hedw.) Brid., Pohlia nutans (Hedw.) Lindb., Ceratodon purpureus (Hedw.) Brid., Polytrichum piliferum Hedw. and P. juniperinum Hedw., 27 November 2001, leg. D. Broughton $11 F$ (KRAM).

Leptobryum pyriforme is a bipolar species with numerous intermediate occurrences on mountains in the tropics. In the cool and cold regions in the western hemisphere, it is widely scattered in western and southern Patagonia (Ochyra et al., 2008b), and it is known from a single record from subantarctic South Georgia (Ochyra et al., 2002) and two stations in the maritime Antarctic (Blockeel et al., 2006b; Ochyra et al., 2008b). Additionally, the species was once recorded in East Falkland Island (Matteri, 1986) and here its range is extended to West Falkland Island. The moss flora of the Falkland Islands is still incompletely known and consists of about 150 species. Matteri (2003) reported 146 species, two subspecies and eight varieties from this archipelago, but no fewer than three species and two varieties from her list are identical to other species and should be excluded from the flora. However, these losses are compensated for by several additional moss species (Allen \& Magill, 2003; Blockeel et al., 2003; Bednarek-Ochyra \& Ochyra, 2003; Ochyra \& Broughton, 2004; Ireland et al., 2005; Ellis et al., 2010, 2011b).

\section{Leptodontium proliferum Herzog}

Contributor: R. Ochyra

Îles Crozet, Île de la Possession: (1) south slopes of valley of Rivière du Camp, $46^{\circ} 25^{\prime} 22^{\prime \prime} \mathrm{S}, 51^{\circ} 51^{\prime} 32^{\prime \prime} \mathrm{W}$, $75 \mathrm{~m}$ a.s.1., on exposed dry soil near penguin colony, 11 January 1979. leg. B. G. Bell 1763 (AAS, KRAM); (2) Crique du Navire, centre of La Grande Manchotiere, $46^{\circ} 25^{\prime} 32^{\prime \prime} \mathrm{S} 51^{\circ} 51^{\prime} 40^{\prime \prime} \mathrm{W}, 0 \mathrm{~m}$ a.s.1., on sides of hummocks in wallows, 24 March 1979, leg. B. G. Bell 3036 (AAS, KRAM); (3) south bank of Crique de Navire, near beach, $46^{\circ} 25^{\prime} 35^{\prime \prime} \mathrm{S} 51^{\circ} 51^{\prime} 39^{\prime \prime} \mathrm{W}, 5 \mathrm{~m}$ a.s.1., on side of Poa annua L. covered earth mound in penguin rookery, 12 February 1979. leg. B. G. Bell 2497 (AAS, KRAM); (4) shore at Crique de Noel, 46 $27^{\prime} 21^{\prime \prime} \mathrm{S}$ $51^{\circ} 50^{\prime} 27^{\prime \prime} \mathrm{W}, 5 \mathrm{~m}$ a.s.1., on side of Poa annua hummock, in penguin affected zone, 26 February 1979. leg. B. G. Bell 2616 (AAS, KRAM); above rocky cliffs on south-side of Crique de la Chaloupe, $46^{\circ} 24^{\prime} 34^{\prime \prime} \mathrm{S} 51^{\circ} 51^{\prime} 33^{\prime \prime} \mathrm{W}, 50 \mathrm{~m}$ a.s.1., on dead Poa hummock, 7 January 1979. leg. B. G. Bell 1680, $1682 \& 1683$ (AAS, KRAM).

For a long time Leptodontium proliferum was considered an altimontane neotropical species known to occur in Bolivia, Peru and Colombia in South America (Churchill et al., 2000) and extending to Mexico in North America (Zander, 1994). Additionally, it was once recorded from the subantarctic Prince Edward Islands (van Zanten, 1971). This classical distribution pattern, exhibited by a number of moss species (e.g. Ochyra et al., 2013; Ochyra \& Bednarek-Ochyra, 2014, 2015), was disturbed as the result of a taxonomic conclusion presented by Zander (1972) who reduced L. proliferum to synonymy with L. gemmascens (Mitt.) Braithw., a western European endemic species (Porley, 2008). However, as convincingly showed by Porley \& Edwards (2010), the two species are definitely distinct and L. proliferum is readily distinguished by its dimorphic leaves, elongated marginal cells and costa excurrent as a proboscis. In young leaves, the proboscis produces gemmae in great profusion, usually over 100 per cluster. The species was lately discovered in Lesotho in southern Africa, which established its Afro-American range, a distribution pattern exhibited by over 80 species of moss (e.g. Buck \& Griffin, 1984; Ochyra et al., 1992; Delgadillo, 1993; Wilbraham \& Matcham, 2010). Some of the species with this distribution pattern extend to subantarctic islands in the Kerguelen Biogeographical Province in the South Indian Ocean, and L. proliferum is a typical example of this type of distribution. The species is widespread in the Prince Edward Islands where it is apparently a post-glacial immigrant (Van der Putten et al., 2010), growing in the coastal areas at low elevations, usually in tussock grasslands dominated by Poa cookii (Hook.f.) Hook.f. on well drained soil on slopes with a moderate to strong influence of animals, including seals and penguins (Gremmen, 1981). Herein, the range of L. proliferum is extended to the Îles Crozet, a subantarctic archipelago situated about $900 \mathrm{~km}$ to the east of the Prince Edward Islands, where it grows in similar environmental conditions. This is a remarkable 
addition to the moss flora of this archipelago, which until recently was the least studied of all subantarctic islands. As a result of intensive field studies, a good number of species have been added to the moss flora (e.g. Blockeel et al., 2006a; Ellis et al., 2014b), which currently consists of about 70 species.

10. Niphotrichum pygmaeum (Frisvoll) BednarekOchyra \& Ochyra

Contributor: R. Ochyra

U.S.A., Oregon: Clackamas County, Mt. Hood, above Timberline Lodge, ca $45^{\circ} 10^{\prime} \mathrm{N} 121^{\circ} 50^{\prime} \mathrm{W}$, on silty slope, 17 August 1979, leg. W. B. Schofied \& J. H. Lyford 74075 (KRAM, UBC).

Niphotrichum pygmaeum is the rarest and smallest species of the genus Niphotrichum Bednarek-Ochyra \& Ochyra, which has hitherto only been known from a few collections in narrow coastal areas of southern British Columbia and Washington (Frisvoll, 1983; Ochyra \& Bednarek-Ochyra, 2007b). Herein, its geographical range is extended to the Cascade Volcanic Arc in northern Oregon. The species is known only in the barren state, sporophytes have never been found. The Pacific coast of North America north of Mexico is a remarkable centre of species diversity for the Racomitrioideae, which consists of five genera of the traditionally broadly conceived genus Racomitrium Brid. (Sawicki et al., 2015). Of 28 species of this subfamily now known to occur in North America (Ochyra, 2007), no fewer than ten are endemics of the western part of the continent, including five species of Bucklandiella Roiv., one of Niphotrichum, one of Frisvollia Sawicki, Szczecińska, Bednarek-Ochyra \& Ochyra and three of Codriophorus P.Beauv. (Bednarek-Ochyra, 2000, 2006).

11. Orthotrichum vladikavkanum Vent.

Contributors: V. Plášek, A. Nowak, M. Nobis, J. Sawicki and L. Ć́hal

Middle Asia, Kyrgyzstan: Tian-Shan Range, 66 km E from Issyk Kul lake, $42 \mathrm{~km}$ E of Karakol City, valley of Turgen-Aksu, on bark of Picea schrenkiana Fisch. \& C.A.Mey. along public road (No. A364), GPS coordinates (WGS 84): $42^{\circ} 30^{\prime} 10.8^{\prime \prime} \mathrm{N}$ 78 55'57.4"E, $2622 \mathrm{~m}$ a.s.1., 14 June 2013, leg. V. Plášek (OSTR \# B265).

A total of 19 taxa of the genus Orthotrichum (incl. Nyholmiella) have previously been reported from Kyrgyzstan (Lazarenko, 1938; Rakhmatulina, 1970, 1990; Lewinsky-Haapasaari, 1994; Mamatkulov et al., 1998; Ignatov et al., 2006; Ellis et al., 2014a,c, 2015a,b). The specimen cited above is an epiphytic moss new to the bryoflora of the country.

Orthotrichum vladikavkanum was first described by Venturi (1887) from the vicinity of Vladikavkaz (Republic of North Ossetia-Alania). Subsequently the species was not recorded for more than a century and was considered to have vanished. However, Ignatov \& Lewinsky-Haapasaari (1994) found it in the Altai Mountains in South Siberia. Owing to intensive field research, new data regarding its occurrence have been published during the last few years. Currently, the species is known from the Caucasus (Venturi, 1887; Akatova, 2002; Akatova et al., 2004; Otte, 2004), Pontic Mountains (Lara et al., 2010), Altai Mountains (Ignatov \& Lewinsky-Haapasaari, 1994; Hradílek et al., 2011), and now also from the Tian-Shan Mountains.

In Kyrgyzstan, Orthotrichum vladikavkanum was first collected in 2013 by a Czech-Polish expedition. It occurred in the eastern part of the country in a montane area of the Tian-Shan Range. The species grew on the bark of a solitary Picea schrenkiana along a public road. The moss cushions were located at 1.5 and $2 \mathrm{~m}$ above the ground, with an eastern exposure. All of the populations were richly fertile. Examples of associated species include Orthotrichum speciosum Nees and $O$. crenulatum Mitt.

Superficially, Orthotrichum vladikavkanum closely resembles $O$. speciosum, but it can be easily distinguished, even in the field, by the configuration of its peristome. Although both species have an exostome formed by 8 pairs of teeth, the number of endostome segments differs; 8 in $O$. speciosum and 16 in $O$. vladikavkanum. Moreover, the endostome segments in the latter species are orange and remarkably broad (almost as wide as the teeth) while in $O$. speciosum they are thin and white.

\section{Plagiothecium membranosulum Müll.Hal.}

\section{Contributor: R. Ochyra}

Kenya: (1) bushland in Limuru near Nairobi, $1^{\circ} 06^{\prime} \mathrm{S} 36^{\circ} 38^{\prime} \mathrm{E}, 7000 \mathrm{ft}[=2290 \mathrm{~m}$ ] a.s.1., tree trunk, February 1915, leg. E. Dümmer 1761, det. H. N. Dixon as Plagiothecium monbuttoviae (Müll.Hal.) A.Jaeger (BM - Hb. Dixon - BM000670409); (2) Mount Kenya, $0^{\circ} 09^{\prime} \mathrm{S} \quad 37^{\circ} 18^{\prime} \mathrm{E}, \quad 6500-12500 \mathrm{ft}$ [=1980-3810 m] a.s.1., 1924, leg. A. Allan 1034 (BM - Hb. Dixon BM000670412); (3) Nyandarua County (former Central Province), Kinangop north of Nairobi, $0^{\circ} 36^{\prime} \mathrm{S} 36^{\circ} 42^{\prime} \mathrm{E}, 4000 \mathrm{~m}$ a.s.l., 20 February 1910, leg. G. Balbo 481 (BM - Hb. Dixon BM000670410); (4) same region, Gasongori hill, Tuthu forest, $2400 \mathrm{~m}$ a.s.1., on trees, 26 August 1908, leg. G. Balbo $472(\mathrm{BM}-\mathrm{Hb}$. Dixon BM000670411).

Plagiothecium membranosulum is widespread in southern Africa, including the Republic of South Africa and Lesotho (O'Shea, 2006), and is also known from Rwanda and Uganda in Central Africa (Ellis et al., 2014a) and in the Kilimanjaro Mountains in Tanzania (Ellis et al., 2012c) in East Africa. Additionally, the species is known from the isolated station on Réunion Island in the East 
Indian Ocean (Ellis et al., 2011a). Here, the East African range of $P$. membranosulum is extended to Kenya where the species was recorded in the southern and central part of the country. In Central Province, it reaches its highest elevation of $4000 \mathrm{~m}$ a.s.1. Like elsewhere, the moss occurred epiphytically on tree boles in the montane rain forests at low and high elevations.

\section{Reboulia hemisphaerica (L.) Raddi} subsp. australis R.M.Schust.

Contributors: E. A. Borovichev and V. A. Bakalin

China. Guizhou Province, Guiyaang City area, Qianling Park, 26 $35^{\prime} 38.9^{\prime \prime} \mathrm{N} 106^{\circ} 41^{\prime} 32.5^{\prime \prime} \mathrm{E}, 1100$ a.s.l., broadleaved (mostly evergreen) forest on steep slope to valley, moist bare clay, in part shade, in mats, with female receptacle and antheridia, 18 November 2013, leg. V.A. Bakalin (VBGI: China50-40-13; duplicate in KPABG).

This is the first report of Reboulia hemisphaerica subsp. australis in China. The nearest other records for the subspecies are in Krasnoyarsk Territory and Republic of Tyva (Russian Siberia) (Ellis et al., 2014b). The subspecies has a disjunctive distribution; it has also been reported from eastern North America, New Zealand (Schuster, 1985), southern Europe (Schuster, 1992), northern Europe (Damsholt, 2002) and the Caucasus (Konstantinova, 2011).

14. Riccia atromarginata Levier

Contributors: C. Sérgio and I. Melo

Cape Verde: Fogo (Fogo Island), Santa Catarina do Fogo, Monte Escora, on soil associated with Riccia crinita Taylor, $14^{\circ} 51^{\prime} 58^{\prime \prime} \mathrm{N} \quad 24^{\circ} 20^{\prime} 29^{\prime \prime} \mathrm{W}$, $754 \mathrm{~m}$ a.s.1., 25 September 2010, leg. I. Melo \& J. Cardoso (LISU257388).

Riccia atromarginata is here newly recorded for the bryoflora of the Cape Verde Archipelago which expands its latitudinal range to almost $14^{\circ}$ N. In Europe, it is widely distributed in the Mediterranean area (Jovet-Ast, 1986; Bischler, 2004), but not in sub-Saharan Africa, while only $R$. atromarginata var. jovet-astiae Rauh \& Buchloh is reported from Madagascar and Socotra (Kürschner, 2000).

In Macaronesia, $R$. atromarginata is known from the Canary Islands and Madeira (Ros et al., 2007). It can be considered an amphi-atlantic species as its occurrence is also mentioned in few areas in the central part of America, in Mexico and Texas (BischlerCausse et al., 2005). $R$. atromarginata is restricted to open habitats in semi-arid and arid areas with high drought conditions.

Sporophytes were observed in the specimen, and the spores exhibited the characteristic features of the species, such as their large size, up to $125 \mu \mathrm{m}$ diameter, and the absence of a wing.

15. Riccia crinita Taylor

Contributors: C. Sérgio and I. Melo
Cape Verde: Fogo (Fogo Island), Santa Catarina do Fogo, Monte Escora, on soil associated with Riccia atromarginata Levier, $14^{\circ} 51^{\prime} 58^{\prime \prime} \mathrm{N}$ $24^{\circ} 20^{\prime} 29^{\prime \prime} \mathrm{W}, 754 \mathrm{~m}$ a.s.1., 25 September 2010, leg. I. Melo \& J. Cardoso (LISU257387).

This is the first report of Riccia crinita in Cape Verde. Jovet-Ast (2000) synonymized Riccia trichocarpa Howe with this name and reported it from many areas with Mediterranean and tropical influences. Elsewhere in the world, it is known from Africa (Perold, 1999), North and South America (Jovet-Ast, 1991), and Australia (Jovet-Ast, 2000). The known distribution of $R$. crinita, as recorded by Jovet-Ast (1986), Bischler (2004), Söderström et al. (2002) and Ros et al. (2007) includes: BosniaHerzegovina, Baleares, Canary Islands, Corsica, Crete, Algeria, Spain, France, Greece, Croatia, Italy, Lebanon, Libya, Morocco, Montenegro, Portugal, Serbia and Tunisia in the Mediterranean Region. Its distribution can therefore be regarded as sub-cosmopolitan, frequently occurring in semiarid and arid zones, on soil crusts (e.g. Australia see Eldridge \& Tozer, 1996).

\section{Riccia macrocarpa Levier}

Contributors: C. Sérgio and I. Melo

Cape Verde: Sto Antão Island, Porto Novo, Pico da Cruz, on exposed soil over rocks, $17^{\circ} 06^{\prime} 19^{\prime \prime} \mathrm{N}$ $25^{\circ} 02^{\prime} 46^{\prime \prime} \mathrm{W}, 1447 \mathrm{~m}$ a.s.l., 29 September 2010, leg. I. Melo \& J. Cardoso (LISU257378).

Until 1992 Riccia macrocarpa was considered a Mediterranean species (Jovet-Ast, 1986) known to occur in the majority of countries from Portugal to Turkey, and including Madeira and the Canary Islands (Ros et al., 2007).

However, Sérgio in 1992 whilst revising the type of $R$. macrocarpa and some specimens of the North American species, Riccia campbelliana M.Howe from its original locality (NY, MO), concluded that these species were indistinguishable and should be considered conspecific. This suggested a much broader distribution for this species, also including a record from South Africa (Perold \& Volk, 1988; Perold, 1991, 1999). Wheeler (2000), in a molecular phylogenetic study of the genus Riccia, confirmed that the two entities were indeed conspecific and presented the distribution of the species in an interesting map. It is suggested that this liverwort may have dispersed across the land prior to the fission of Pangea.

Herein, the distribution of this Riccia is extended to West Africa, being found on a small Island of the Cape Verde Archipelago. The present discovery on Sto. Antão Island, fills the gap in its African and Macaronesian distribution.

R. macrocarpa is scarce in South Africa, occurring mainly in the lowlands, and is also recorded from Socotra (Kürschner, 2003; Wigginton, 2004). 
In summary, the species has a bicentric distribution, with one centre in the Old World, in the Mediterranean region and scattered in southern and eastern Africa, and a second centre of occurrence in North America where it has been reported from California to the Gulf of Mexico (Wheeler, 2000).

In the Mediterranean region, $R$. macrocarpa prefers acidic and dry soils (Bischler, 2004). The present collection from Sto. Antão Island was found in an area of volcanic origin, more or less exposed near $1500 \mathrm{~m}$ a.s.1., associated with Exormotheca pustulosa Mitt., Plagiochasma rupestre (G.Forst.) Steph., Mannia androgyna (L.) A.Evans, Didymodon australasiae (Hook. \& Grev.) R.H.Zander, Bryum canariense Brid., Pleurochaete squarrosa (Brid.) Lindb., Ptychomitrium subcrispatum Thér. \& P.de la Varde, Bryum apiculatum Schwägr., Campylopus pilifer Brid., and some lichens in the genera Cladonia P.Browne, Anaptychia L. and Toninia A.Massal.

17. Riella mediterranea Segarra-Moragues, Puche, Sabovljević, Infante \& Heras

Contributors: I. Tziortzis and R. Barone

Cyprus: Paralimni Lake, Famagusta district $35^{\circ} 01^{\prime} 54.16^{\prime \prime} \mathrm{N} 33^{\circ} 58^{\prime} 22.87^{\prime \prime} \mathrm{E}, 67 \mathrm{~m}$ a.s.l. sediments collected on 19 September 2013, leg. I. Tziortzis s.n., det. R. Barone (Herbarium of Rossella Barone).

Cultures of sediments collected from the east shore of Paralimni Lake during the dry phase of the lake revealed a population of Riella Mont. Paralimni Lake is a slightly brackish seasonally flooded shallow body of water in the southeast part of Cyprus. The examination of the gametophytes showed that they corresponded to a dioicous species, and both male and female individuals appeared in culture. Female plants developed winged archegonial involucres which is indicative of species in the subgenus Trabutiella Porsild. These involucres were acuminate and showed discontinuous wings (10-12), as is characteristic of the recently described $R$. mediterranea (Segarra-Moragues et al., 2014). The unreticulated spores $(108-120 \times 106-118 \mu \mathrm{m})$, showed distal spines rounded at the apex $(12-16 \mu \mathrm{m})$ and acute proximal spines $(6-10 \mu \mathrm{m})$. Riella (Montagne, 1852) has a worldwide distribution and includes about 24 taxa that commonly grow submerged in clean, shallow, fresh or brackish waters of seasonal ponds, streams, and more rarely, in permanent lakes in arid or semiarid regions. About half of these species are found growing in the Mediterranean basin (Segarra-Moragues et al., 2014). Riella mediterranea is a dioicous liverwort belonging to the subgenus Trabutiella of the Riellaceae family. It has only recently been recognised as a distinct species, since previous studies repeatedly misidentified specimens as other species such as $R$. helicophylla or $R$. cossoniana (Segarra-Moragues et al., 2014).
According to the authors, $R$. mediterranea is found submerged in seasonal ponds of fresh to slightly brackish water in Spain (including the Balearic Islands), Malta and Israel; recently $R$. mediterranea was found in two ephemeral Moroccan lakes (Ellis et al., 2014c). These conditions are also met in Paralimni Lake. This is the first record of the species for Cyprus and the second of the genus Riella (Ellis et al., 2012a).

\section{Scapania schljakovii Potemkin}

Contributors: Y. Xiong and V. A. Bakalin

China: Yunnan Province, Gongshan County, east slope of Gaoligong Shan, Qi Qi trail above Dengxiaofang, $23^{\circ} 41^{\prime} 43^{\prime \prime} \mathrm{N} 98^{\circ} 28^{\prime} 06^{\prime \prime} \mathrm{E}, 3333 \mathrm{~m}$ a.s.l., outcrop above stream, 27 September 2006, leg. D.G. Long \& J.R. Shevock 37152 (MO-6230476, duplicate in VBGI).

Scapania schljakovii was described relatively recently (Potemkin, 2001) from Sikkim in India and until now was only known from the type locality. The species was regarded as the most advanced member of Scapania (Dumort.) Dumort. sect. Scapania. It resembles $S$. ornithopodioides (With.) Waddell, but differs in several characters, including its nondecurrent leaf lobes, relatively large dorsal lobe and the shape of the trigones in its leaf cells. Another relative of $S$. schljakovii is $S$. himalayica Müll.Frib., which differs from the former in having leaf margins with fuscous borders and regularly dentate to the base, cells less thickened in mid-lobe and thickened cell walls along the leaf margin. This present observation confirms $S$. schljakovii as a distinct species and extends its known distribution. Taking in to account the close relationships between the hepatic floras of the Himalayas and Yunnan, this new record was not unexpected.

19. Schistidium rivulariopsis (R.S.Williams) Ochyra Contributor: R. Ochyra

Colombia: Departamento Santander, vicinity of Vetas, 3100-3250 $\mathrm{m}$ a.s.1., open rocky hillsides, on wet rock, 16-20 January 1927, leg. E. P. Killip \& A. C. Smith 17392 (US).

Schistidium rivulariopsis is a neglected Andean species which until recently was considered to be conspecific with $S$. rivulare (Brid.) Podp. (Deguchi, 1987). However, it has been reinstated as a species in its own right (Ochyra \& Bednarek-Ochyra, 2011), and differs from $S$. rivulare in its possession of small and minutely papillose spores, 12-13 $\mu \mathrm{m}$ diam., the lack of stomata and entire margins at the leaf apex. The species has hitherto been known only from the type material from Peru, and here its range is extended to the northern Andes of Colombia. Bartram (1955) reported it from Ecuador, but his material does not belong within this species (Ochyra \& Bednarek-Ochyra, 2011). Schistidium 
rivulariopsis is a rheophytic moss growing in montane brooks, usually in swiftly flowing water or on otherwise wet rocks. Consequently, it exhibits some adaptations to this type of habitat, of which the most important is the presence of multistratose fleshy limbidia that extend from the leaf base to the apex, and strongly excurrent, multistratose costae (Ochyra, 1985, 1987).

\section{Syntrichia calcicola J.J.Amann}

Contributor: C. Sérgio and C.A. Garcia

Portugal: Trás-os-Montes e Alto Douro, pr. Silva, to Campo das Víboras, 29TQF1398, $650 \mathrm{~m}$ a.s.1., on wet slope of a crystalline limestone quarry, August 2002, leg. Gabriel Sérgio (LISU 257333).

In the course of studying bryophyte collections from north-eastern Portugal, some remarkable species of phytogeographical and ecological significance were identified, one of them, Syntrichia calcicola, being a new record for the Portuguese bryoflora.

This species was found growing on basic rocks in a mineral-rich, very exposed calcareous habitat. It was easily recognized by the morphological characteristics of the gametophyte, with leaves ovate and not constricted in mid-leaf; leaf margins recurved almost to $2 / 3$ of the lamina, costa without hydroids and mid-lamina cells that vary from 12 to $18(-20)$ $\mu \mathrm{m}$ diam.

In the same area we found Syntrichia princeps (De Not.) Mitt., S. montana Nees, S. ruralis (Hedw.) F.Weber \& D.Mohr, Encalypta vulgaris Hedw., Grimmia pulvinata (Hedw.) Sm. and Schistidium helveticum (Schkuhr) Deguchi, which grow nearby, or almost in close association.

The soil in the region was predominantly acidic. However, it is a geologically complex area, with carbonate rocks, sandstones, clays, shale, and greywacke, among other less representative rocks. The annual mean precipitation is $c a 650 \mathrm{~mm}$ and the annual mean temperature is $11^{\circ} \mathrm{C}$ with ca 2600 annual hours of sunlight.

Syntrichia calcicola is a widespread species, distributed in Europe, south-western Asia and in some countries of the Mediterranean basin, from North Africa (Morocco) to Turkey, but not in Macaronesia (Gallego et al., 2002; Ros et al., 2013). It is relatively common in Spain and in Mallorca (Gallego, 2006; Casas et al., 2006), so this new occurrence in Portugal extends the known distribution of the species into the western Iberian Peninsula. Moreover, its habitat conforms to the typical ecological preferences of this element of the family Pottiaceae.

21. Syntrichia minor (Bizot) M.T.Gallego, J.Guerra, M.J.Cano, Ros \& Sánchez-Moya

Contributor: V. Hugonnot
France: Haute-Loire, Coubon, Orzilhac, MontSaint-Maurice, $03^{\circ} 56^{\prime} 08.5^{\prime \prime} \mathrm{E} \quad 45^{\circ} 01^{\prime} 02.2^{\prime \prime} \mathrm{N}, 750 \mathrm{~m}$ a.s.1., 2 September 2014, leg. V. Hugonnot s.n. (Herb. Conservatoire botanique national du Massif central)

The material collected in Haute-Loire possessed features entirely matching those of Syntrichia minor. The leaf cells with branched, pedicellate papillae were most characteristic, leaf margins were plane or weakly recurved at the leaf base, and the costa in transverse section failed to show hydroids. $S$. minor is reported to be dioicous (Gallego, 2005), but the collected specimens were sterile, without gametangia or sporophytes.

The taxonomy of Syntrichia minor has been clarified in recent times (Gallego et al., 2000). Following these authors, $S$. minor is best considered as a separate species and not as a subspecies of $S$. virescens (DeNot.) Ochyra as presented in Ochyra (1988) and Kramer (1980). The type of papillae adorning the leaves is most important in distinguishing $S$. virescens from $S$. minor. In $S$. minor, the lumen of each cell strongly protrudes from both sides of the leaf in a high columnar, hollow conical projection, crowned with digitiform extensions. By contrast, in $S$. virescens the cells are covered with 2-4 low papillae. Otherwise, $S$. minor shares with $S$. virescens the mostly plane leaves, constricted lamina, poor development of stereid bands and absence of hydroids. The overall appearance of the plants is very similar in the field, although $S$. minor can show a more pronounced glaucous tinge owing to its peculiar type of papillae. $S$. minor could be confused with two species that possess similar papillae, namely $S$. echinata (Schiffn.) Herrnst. \& Ben-Sasson and S. papillosissima (Copp.) Loeske. Syntrichia minor differs from S. echinata by its lack of hydroids and from $S$. papillosissima by its mid-leaf constriction, and in the latters more numerous dorsal layers of stereids in the costa (Gallego, 2005). Syntrichia echinata and S. papillosissima are not recorded for France.

Syntrichia minor was observed in very small cushions of $10 \mathrm{~cm}^{2}$ at the base of a basaltic cliff with a south-west aspect. Immediate associates included Grimmia laevigata (Brid.) Brid., G. ovalis (Hedw.) Lindb. and Schistidium flaccidum (De Not.) Ochrya. This type of bryophyte vegetation is classically referred to the association Grimmietum commutatocampestris v. Krus. 1945 which is a typical, and very extensive, community colonizing basaltic dry rocks in full sun. Syntrichia minor was previously thought of as an epiphyte (Gallego et al., 2000; Gallego, 2006) but has been found in rock fissures with accumulated soil (Gallego, 2005). The present record demonstrates that the species can also grow directly on rocks. It is recorded from Cyprus on an 
old juniper tree (Blockeel, 2003), a substrate which typically and frequently harbours rock-dwelling species. It was recorded on unprotected soils on limestone (Blockeel et al., 2002) but the species could well prove to be rather indifferent to the nature of rock.

Syntrichia minor is predominantly a Mediterranean species, known to occur in North Africa (Morocco), southwest Asia (Lebanon), Macaronesia and Europe (Canary Islands, Cyprus, Greece, Spain; Gallego, 2005). The species had not been recorded in France, and the Auvergne locality marks a significant northward extension of its known distribution. It is apparently a rare species worldwide. Given that basaltic outcrops at comparable altitudes are very frequent and most often host a similar bryoflora, $S$. minor is almost certainly under-recorded. This type of habitat is generally totally free of human disturbance so that conservation of the associated bryoflora is not problematic.

\section{Syntrichia norvegica F. Weber}

Contributors: A. Alegro, V. Šegota and B. Papp

Croatia: Dinaric Alps, northern Velebit Mountains, Rožanski kukovi peaks area, bottom of deep doline, north from Novotnijev kuk peak, $44^{\circ} 45^{\prime} 56.1^{\prime \prime} \mathrm{N} \quad 14^{\circ} 59^{\prime} 25.4^{\prime \prime} \mathrm{E}, \quad 1540 \mathrm{~m}$ a.s.1., $\mathrm{NE}$ exposure, in stands of the frigoriphilous herb community Drepanoclado uncinati-Heliospermetum pusillae, and the adjacent low shrub community Salicetum waldsteinianae, 19 September 2014, leg. et det. A. Alegro s.n. (Herb. ZA).

Syntrichia norvegica is a circumpolar arctic-montane species (Smith, 2004), rare at lower altitudes and in southern Europe (Frey et al., 2006). It is known from several south-eastern European countries (Sabovljević et al., 2008) and now it is recorded for the first time in Croatia. Regarding its conservation status, $S$. norvegica is red listed in Great Britain (EN), Czech Republic (CR), Slovakia (VU), Bulgaria (NT), Hungary (DD), Romania (VU) and Estonia (VU) (Hodgetts, 2014).

It was found in the northern Velebit Mountains, in an area with the most outstanding and extreme karst relief, with steep slopes, perpendicular rocks, screes and deep dolines. The locality is situated in the Pinus mugo Turra belt, but owing to its position in the shaded bottom of a deep, funnel-shaped doline with slopes inclined at more than $70^{\circ}$, the zonal vegetation is replaced by frigoriphilous communities. The main community on the very bottom is Drepanoclado uncinati-Heliospermetum pusillae Surina \& Vreš 2004, which encompasses many species of cold habitats characterized by long-lasting snow cover, e.g. Saxifraga sedoides L. subsp. prenja (Beck) Beck (glacial relict in the Velebit), Heliosperma pusillum (Waldst. \& Kit.) Rchb., Polygonum viviparum L., Myosotis alpestris F.W.Schmidt, Poa alpina L. and
Festuca nitida Kit. This community was spread over ca $250 \mathrm{~m}^{2}$ and was bordered by low shrubs of Salix waldsteiniana Willd., which form another frigoriphilous community Salicetum waldsteinianae Beger 1922. In the moss flora, another arctic-montane species, Cyrtomnium hymenophylloides (Huebener) T.J.Kop., is very abundant, and this is the only known locality in Croatia (Blockeel et al., 2009c). Further bryophytes that were present include Sanionia uncinata (Hedw.) Loeske, Orhothecium rufescens (Dicks. ex Brid.) Schimp., Campylium protensum (Brid.) Kindb., Campylophyllum halleri (Hedw.) M.Fleisch., Sciuro-hypnum reflexum (Starke) Ignatov \& Huttunen, Platydictya jungermannioides (Brid.) H.A.Crum, Hypnum bambergeri Schimp., Plagiopus oederianus (Sw.) H.A.Crum \& L.E.Anderson, and Plagiochilla porelloides (Torr. ex Nees) Lindenb. among others.

The population of $S$. norvegica was vigorous, forming dozens of dense patches of several $\mathrm{dm}^{2}$ on rocks and among other bryophytes and herbs. Plants were typically developed, deep green, with long, reddish leaf points, but capsules were not found.

23. Tetraplodon angustatus (Hedw.) Bruch \& Schimp.

Contributor: V. Hugonnot

France: Haute-Loire, Freycenet-la-Cuche, forêt domaniale du Mézenc, Roche du Bachat, $04^{\circ} 05^{\prime} 33.3^{\prime \prime} \mathrm{E}, 44^{\circ} 55^{\prime} 00.6^{\prime \prime} \mathrm{N}, 1360 \mathrm{~m}$ a.s.l., 5 August 2014, leg. V. Hugonnot s.n. (Herb. Conservatoire botanique national du Massif central)

The collected specimens possessed narrow leaves with a long subula, which were more or less distinctly serrate in their upper half, and agreed very well with the descriptions provided in Frisvoll (1978) and Crum \& Anderson (1981). The size of individual shoots was very variable, with very small shoots being located at the periphery of the tufts and larger ones in the centre.

The geology consisted of phonolitic lava with a low silica content that formed impressive boulders on the flanks of Roche de Bachat. Five dense clumps of moss, bearing a profusion of sporophytes, were found on fox scats, which had been left scattered as marker points in the scree. The substrate was full of small bones, and no other bryophytes were found in admixture. Otherwise, the bryoflora of the scree was typically composed of Gymnomitrion concinnatum (Lightf.) Corda, Marsupella funckii (F.Weber \& D.Mohr) Dumort. and Racomitrium sudeticum (Funck) Bruch \& Schimp., growing on dry acidic boulders. Tetraplodon angustatus grows mostly on top of rocks and more exceptionally in bogs. It typically colonizes decaying animal carcasses, droppings and bird pellets 
(Cykowska-Marzencka, 2013) in scree, or more exceptionally on ombrotrophic peat-bog (Stebel et al., 2004). It is a common feature of known populations that it occurs in small quantities (Meinunger \& Schröder, 2007).

Tetraplodon angustatus is a boreal montane species with a circumpolar range in the Holarctic. It is known in northern North America, Greenland, Asia and Europe, where it is mostly a Fennoscandian species. In central Europe, it is recorded in the Alps, Sudetes and Carpathians (Szmajda et al., 1991). Its westernmost occurrences are in the Scottish Highlands, the centre of Ireland and north Wales (Rothero, 2014). The Massif Central locality of Tetraplodon angustatus is at the southern limit of its European range. It is not known to occur in the Pyrenees or in the mountains of the Iberian Peninsula.

The genus Tetraplodon is poorly represented in France, with only $T$. angustatus and $T$. mnioides (Hedw.) Bruch \& Schimp. The latter was recently recorded in the Jura (Philippe, 2013). T. angustatus was previously observed in the Alps, on the MontBlanc massive (Husnot, 1884-1894; Vadam, 1976). It is more frequent and widespread in Switzerland, suggesting that it could be under recorded in the French Alps. This is unlikely to be the case in the Massif Central given the limited upper altitude and also because potential habitats are infrequent.

On the scree, $T$. angustatus is free from any direct human impact, but this is not the case in the nearby forests, which are heavily managed. This does not constitute an immediate threat since the scree is not wooded. In France, the fox is classified as a pest that can be hunted year-round and this is beyond doubt the most serious limit to the spread of Tetraplodon, which here is strictly restricted to fox faeces. Between 600,000 and one million foxes are killed each year, with a very significant proportion in the Auvergne. T. angustatus should be added to the Red Data List of Auvergne in the near future.

\section{Acknowledgements}

The work of E. A. Borovichev and V. A. Bakalin was partially supported by the Russian Foundation of Basic Research (grants no. 13-04-00775, 15-0403479) and President's Program for support of PhD research (MK-2926.2015.4). S. Ştefănuţ acknowledges the support of project no. RO1567-IBB03/ 2015 through the Institute of Biology Bucharest of Romanian Academy. The contribution by V. Plášek is part of a research project of the Institute of Environmental Technologies, reg. no. CZ.1.05/ 2.1.00/03.0100, Project LO1208 of the National Feasibility Programme I of the Czech Republic and SYNTHESYS project DE-TAF-4436. V. Hugonnot thanks M.T. Gallego for checking the material of
Syntrichia minor. The work of V. Bakalin was supported by the grants from the Russian Foundation for the Basic Research (13-04-00775, 15-34-20101). The contributions by R. Ochyra have been financially supported by the Polish National Centre of Science through grant No. N N 303796 940. He is also thankful to the Curators at BM, ID, S, UBC and US for the loan of herbarium materials. The field work of R. Ochyra and Marc Lebouvier on the Îles Kerguelen was organised within the programme 136 ECOBIO of the French Polar Institute (IPEV). I. Tziortzis and R. Barone are very grateful to Dr Federico Marrone who enabled the sediment cultivation for all samples and give special thanks to Dr Jose Gabriel Segarra-Moragues, who confirmed the Cyprus specimen as $R$. mediterranea and provided valuable support.

Taxonomic Additions and Changes: Nil.

\section{References}

Akatova, T.V. 2002. Moss flora of the Caucasian Nature Reserve (Western Caucasus, Russia). Arctoa, 11: 179-204. [in Russian]. Akatova, T.V., Kharzinov, Z.K., Ignatova, E.A. \& Ignatov, M.S. 2004. On three rare species of Orthotrichum (Orthotrichaceae, Musci) in the Caucasus. Arctoa, 13: 41-9.

Allen, B. \& Magill, R.E. 2003. A revision of Pilotrichella (Lembophyllaceae, Musci). Acta Academiae Paedagogicae Agriensis Sectio Biologicae Nova Series, 24: 43-83.

Bakalin, V.A., Manvelidze, Z., Kharazishvili, D. \& Memiadze, N. 2013. A small collection of hepatics from Adjara, Georgia. Arctoa, 22: 125-30.

Bartlett, J.K. \& Frahm, J.-P. 1983. Notes on Campylopus and Chorisodontium from New Zealand. Journal of Bryology, 12: 365-82.

Bartram, E.B. 1955. Mosses of the Ecuadorian Andes. Bulletin of the British Museum (Natural History) Botany, 2: 51-64.

Bednarek-Ochyra, H. 2000. Racomitrium ryszardii (Musci, Grimmiaceae), a new hydrophilous species from the Pacific northwest with comments on Racomitrium aquaticum in North America. Cryptogamie, Bryologie, 21(4): 275-84.

Bednarek-Ochyra, H. 2004a. Codriophorus corrugatus (Bryopsida, Grimmiaceae), a new species from East Asia and southern Alaska. Bryologist, 107(3): 377-84.

Bednarek-Ochyra, H. 2004b. Does Racomitrium aciculare occur in China and South Africa? Bryologist, 107(2): 197-201.

Bednarek-Ochyra, H. 2006. A taxonomic monograph of the moss genus Codriophorus $P$. Beauv. (Grimmiaceae). Kraków: W. Szafer Institute of Botany, Polish Academy of Sciences.

Bednarek-Ochyra, H. 2014a. Taxonomic status of two subantarctic species of Philonotis (Bartramiaceae, Musci). Cryptogamie, Bryologie, 35(4): 387-95.

Bednarek-Ochyra, H. 2014b. A taxonomic assessment of Racomitrium steerei (Grimmiaceae, Musci) from Venezuela. Herzogia, 27(1): $141-46$.

Bednarek-Ochyra, H. 2014c. On the identities of some neglected species of Grimmiaceae from Îles Kerguelen. Journal of Bryology, 36(4): 300-5.

Bednarek-Ochyra, H. \& Ochyra, R. 1998. Racomitrium lamprocarpum (Müll.Hal.) Jaeg. - an addition to the moss flora of Îles Kerguelen and the Subantarctic. Journal of Bryology, 20(2): 525-28.

Bednarek-Ochyra, H. \& Ochyra, R. 2000. Racomitrium norrisii sp. nov. (Grimmiaceae, Bryopsida), endemic of western North America. Annales Botanici Fennici, 37(4): 235-41.

Bednarek-Ochyra, H. \& Ochyra, R. 2003. Racomitrium patagonicum, a new moss species from southern South America. Journal of Bryology, 25(3): 181-87.

Bednarek-Ochyra, H. \& Ochyra, R. 2010a. Bucklandiella allanfifei (Grimmiaceae), a new moss species from New Zealand, with a note on South American B. striatipila. Journal of Bryology, 32(4): $245-55$. 
Bednarek-Ochyra, H. \& Ochyra, R. 2010b. Bucklandiella shevockii (Grimmiaceae), an exquisite new species from Yunnan, China. Polish Botanical Journal, 55(2): 499-506.

Bednarek-Ochyra, H. \& Ochyra, R. 2012a. The taxonomic status of Racomitrium capense (Bryophyta, Grimmiaceae) from South Africa. Cryptogamie, Bryologie, 33(2): 97-106.

Bednarek-Ochyra, H. \& Ochyra, R. 2012b. A consideration of Bucklandiella (Bryophyta, Grimmiaceae) in South America, with a taxonomic re-assessment of Racomitrium looseri. Nova Hedwigia, 95(1-2): 153-63.

Bednarek-Ochyra, H. \& Ochyra, R. 2013. Diversity of Grimmiaceae subfam. Racomitrioideae in sub-Saharan Africa, including an addition of Bucklandiella striatipila to the moss flora of the continent. Cryptogamie, Bryologie, 34(1): 3-12.

Bednarek-Ochyra, H., Seppelt, R.D. \& Ochyra, R. 2010. Niphotrichum muticum (Musci, Grimmiaceae), an addition to the moss flora of the Aleutian Islands. Botany, 88(4): 389-96.

Bell, B.G. 1974. A synoptic flora of South Georgian mosses: V Willia and Racomitrium. British Antarctic Survey Bulletin, 38: 73-101.

Bischler, H. 2004. Liverworts of the Mediterranean. Ecology, diversity and distribution. Stuttgart: Gerbrüder Borntraeger.

Bischler-Causse, H., Gradstein, S.R., Jovet-Ast, S., Long, D.G. \& Salazar Allen, N. 2005. Marchantiidae. Flora Neotropica, 97: $25-123$.

Blockeel, T.L. 2003. New records of bryophytes from Cyprus Bocconea, 16: 105-11.

Blockeel, T.L., Ros, R.M., Sabovljevic, M., Cano, M.J., Gallego, M.T. \& Muñoz, J. 2002. New and interesting bryophyte records for Greece. Cryptogamie, Bryologie, 23: 149-55.

Blockeel, T.L., Abay, G., Çetin, B., Bednarek-Ochyra, H., Ochyra, R., Lewis Smith, R.I., Matteri, C.M., Farias, R.M., Novotný, I., Rao, P., Enroth, J., van Rooy, J., Schiavone, M.M. \& Ván̆a, J. 2003. New national and regional bryophyte records, 7. Journal of Bryology, 25(2): 141-44.

Blockeel, T.L., Chlebicki, A., Hájková, P., Hájek, M., Hradílek, Z., Kürschner, H., Ochyra, R., Parolly, G., Plášek, V., Quandt, D. Townsend, C.C. \& Vanderpoorten, A. 2006a. New national and regional bryophyte records, 12. Journal of Bryology, 28(1): 68-70.

Blockeel, T.L., Bednarek-Ochyra, H., Ochyra, R., Hájková, P., Hájek, M., Kučera, J., Kürschner, H., Müller, F., Oliván, G. Parolly, G., Porley, R.D., Rams, S., Séneca, A., Sérgio, C., Townsend, C.C., Tyshchenko, O. \& Vieira, C. 2006b. New national and regional bryophyte records, 13. Journal of Bryology, 28(2): 151-55

Blockeel, T.L., Bednarek-Ochyra, H., Ochyra, R., Düzenli, A., Erdağ, A., Erzberger, P., Ezer, T., Hespanhol, H., Kara, R., Matteri, C.M., Müller, F., Séneca, A., Sérgio, C. \& Váňa, J. 2007a. New national and regional bryophyte records, 15. Journal of Bryology, 29(2): 139-42.

Blockeel, T.L., Bednarek-Ochyra, H., Ochyra, R., Garilleti, R., Glime, J.M., Lara, F., Mazimpaka, V., Rusińska, A., Schaefer-Verwimp, A. \& Shabbara, H.M. 2007b. New national and regional bryophyte records, 17. Journal of Bryology, 29(4): 277-83.

Blockeel, T.L., Bednarek-Ochyra, H., Ochyra, R., Duckett, J.G. Erzberger, P., Hedenäs, L., Hugonnot, V., Maier, E. Seppelt, R.D., Thouvenot, L. \& van Zanten, B.O. 2008. New national and regional bryophyte records, 18. Journal of Bryology, 30(2): 161-67.

Blockeel, T.L., Bakalin, V.A., Bednarek-Ochyra, H., Ochyra, R. Buck, W.R., Choi, S. \& Cykowska, B. 2009a. New national and regional bryophyte records, 20. Journal of Bryology, 31(1): 54-62.

Blockeel, T.L., Bednarek-Ochyra, H., Ochyra, R., Cykowska, B., Esquivel, M.G., Lebouvier, M., Luis, L. \& Martins, S. 2009b. New national and regional bryophyte records, 21. Journal of Bryology, 31(2): 132-39.

Blockeel, T.L., Bastos, C.J.P., Bednarek-Ochyra, H., Ochyra, R., Dulin, M.V., Fovet, L. \& Garcia, C. 2009c. New national and regional bryophyte records, 22. Journal of Bryology, 31(3): 201-10

Blockeel, T.L., Bednarek-Ochyra, H., Cykowska, B., Ochyra, R. Düzenli, A., Ezer, T., Holyoak, D.T., Hugonnot, V., Kara, R., Larraín, J., Lebouvier, M., Preston, C.D. \& Schäfer-Verwimp, A. 2010. New national and regional bryophyte records, 23 . Journal of Bryology, 32(2): 140-47.

Borovichev, E.A., Kalinauskaite, N. \& Konstantinova, N.A. 2009. On the distribution of Conocephalum conicum and C. salebrosum (Marchantiophyta) in Russia. Arctoa, 18: 115-20.
Buck, W.R. \& Griffin, D. III. 1984. Trachyphyllum, a moss genus new to South America with notes on African-South American bryogeography. Journal of Natural History, 18(1): 63-9.

Cao, T., He, S. \& Vitt, D.H. 2003. Grimmiaceae. In: C. Gao, M.R Crosby \& H. Si, eds. Moss flora of China. Grimmiaceae - Tetraphidaceae, Volume 3. Beijing: Science Press and St. Louis, Missouri Botanical Garden Press. pp. 3-76. [English version]

Cardot, J. 1916. Note sur des mousses de Kerguelen. Bulletin du Muséum d'Histoire Naturelle, 22: 336-41.

Casas, C., Brugués, M., Ros, R.M. \& Sérgio, C. 2006. Handbook of mosses of the Iberian Peninsula and the Balearic Islands. Barcelona: Institut d'Estudis Catalans.

Churchill, S.P., Griffin, D.III \& Muñoz, J. 2000. A checklist of the mosses of the tropical Andean countries. Ruizia, 17: 1-203.

Crum, H.A. \& Anderson, L.E. 1981. Mosses of eastern North America. New York: Columbia University Press.

Cykowska-Marzencka, B. 2013. Tetraplodon angustatus (Bryopsida, Splachnaceae) in the Polish Tatra Mts. Polish Botanical Journal, 58: 613-16.

Damsholt, K. 2002. Illustrated flora of Nordic liverworts and hornworts. Lund: Nordic Bryological Society.

Daubenmire, R.F. 1975. Floristic plant geography of eastern Washington and northern Idaho. Journal of Biogeography, 2(1): $1-18$.

Deguchi, H. 1987. Studies on some Peruvian species of the Grimmiaceae (Musci, Bryophyta). In: H. Inoue, ed. Studies on cryptogams in southern Peru. Tokyo: Tokai University Press. pp. 19-74

Delgadillo, C.M. 1993. The Neotropical-African moss disjunction. Bryologist, 96(4): 604-15

Düll, R. 1984. Distribution of the European and Macaronesian mosses (Bryophytina) I. Bryologische Beiträge, 4: 1-109.

Eldridge, D.J. \& Tozer, M.E. 1996. Distribution and floristics of bryophytes in soil crusts in semi-arid and arid Eastern Australia. Department of Land and Water Conservation, c/o Graduate School of the Environment, Macquarie University, NSW 2109. Australian Journal of Botany, 44: 223-47.

Ellis, L.T., Asthana, A.K., Sahu, V., Bednarek-Ochyra, B.H., Ochyra, R., Cano, M.J., Costa, D.P., Cykowska, B., Ochyra, R., Philippov, D.A., Dulin, M.V., Erzberger, P., Lebouvier, M., Mohamed, H., Ochyra, R., Orgaz, J.D., Phephu, N., van Rooy, J., Stebel, A., Suárez, G.M., Schiavone, M.M., Townsend, C.C., Váňa, J., Vončina, G., Yayintas, ÖT., Yong, K.T. \& Zander, R.H. 2010. New national and regional bryophyte records, 25. Journal of Bryology, 32(4): 311-22.

Ellis, L.T., Bednarek-Ochyra, H., Ochyra, R., Calvo Aranda, S., Colotti, M.T., Schiavone, M.M., Dulin, M.V., Erzberger, P., Ezer, T., Kara, R., Gabriel, R., Hedenäs, L., Holyoak, D.T., Ódor, P., Papp, B., Sabovlević, M., Seppelt, R.D., Smith, V.R., Sotiaux, A., Szurdoki, E., Vanderpoorten, A., van Rooy, J. \& Żarnowiec, J. 2011a. New national and regional bryophyte records, 26. Journal of Bryology, 33(1): $66-73$

Ellis, L.T., Asthana, A.K., Sahu, V., Srivastava, A., BednarekOchyra, H., Ochyra, R., Chlachula, J., Colotti, M.T., Schiavone, M.M., Hradilek, Z., Jimenez, M.S., Klama, H., Lebouvier, M., Natcheva, R., Pócs, T., Porley, R.D., Sérgio, C., Sim-Sim, M., Smith, V.R., Söderström, L., Ştefănuț, S., Suárez, G.M. \& Váňa, J. 2011b. New national and regional bryophyte records, 28. Journal of Bryology, 33(3): 237-47.

Ellis, L.T., Bednarek-Ochyra, H., Cykowska, B., Ochyra, R., Garcia, C., Sérgio, C., Lebouvier, M., Manolaki, P., Giannouris, E., Kadis, C., Marková, I., Papp, B., Szurdoki, E., Peralta, D.F., Plášek, V., Ristow, R., Sabovljević, M., Sim-Sim, M., Smith, V.R., Tsakiri, E., Váňa, J., Virchenko, V.M. \& Barsukov, O.O. 2012a. New national and regional bryophyte records, 30. Journal of Bryology, 34(1): 45-51.

Ellis, L.T., Alegro, A., Bednarek-Ochyra, H., Ochyra, R., Bergamini, A., Cogoni, A., Erzberger, P., Górski, P., Gremmen, N., Hespanhol, H., Vieira, C., Kurbatova, L.E., Lebouvier, M., Martinčič, A., Asthana, A.K., Gupta, R., Nath, V., Natcheva, R., Ganeva, A., Özdemir, T., Batan, N., Plášek, V., Porley, R.D., Randić, M., Sawicki, J., Schröder, W., Sérgio, C., Smith, V.R., Sollman, P., Ştefănuţ, S., Stevenson, C.R., Suárez, G.M., Surina, B., Uyar, G. \& Surina, Z.M. 2012b. New national and regional bryophyte records, 31. Journal of Bryology, 34(2): 123-34.

Ellis, L.T., Bednarek-Ochyra, H., Ochyra, R., Cykowska, B., Dulin, M.V., Ezer, T., Kara, R., Flores, J.R., Suárez, G.M., Garcia, C., Martins, A., Sérgio, C., Garilleti, R., 
Kırmacı, M., Agcagil, E., Kurbatova, L.E., Lebouvier, M., Papp, B., Szurdoki, E., Philippov, D.A., Plášek, V., Pócs, T., Sabovljević, M., Sawicki, J., Sim-Sim, M., Szúcs, P., Bidló, A., Váňa, J., Vigalondo, B., Lara, F., Draper, I., Virchenko, V.M. \& Wolski, G.J. 2012c. New national and regional bryophyte records, 33. Journal of Bryology, 34(4) 281-91.

Ellis, L.T., Asthana, A.K., Gupta, R., Nath, V., Sahu, V., BednarekOchyra, H., Ochyra, R., Cykowska, B., Calvo Aranda, S., Fischer, E., Gabriel, R., Górski, P., Gremmen, N., Hespanhol, H., Kurbatova, L.E., Lewis Smith, R.I., Long, D.G., Bell, D., Mogro, F., Sérgio, C., Garcia, C.A., Stow, S., Martins, A., Smith, V.R., Váňa, J. \& Vanderpoorten, A. 2013a. New national and regional bryophyte records, 34 Journal of Bryology, 35(1): 62-70.

Ellis, L.T., Bednarek-Ochyra, H., Ochyra, R., Benjumea, M.J., Saïs, L.V., Caparrós, R., Lara, F., Mazimpaka, V., Dulin, M.V., Garilleti, R., Gremmen, N., Grundling, P.-L. Heras, P., Infante, M., Huttunen, S., Ignatov, M.S., Korvenpää, T., Lebouvier, M., Lewis Smith, R.I., Lin, S.-H., Yang, J.-D., Linström, A., Plášek, V., Rosselló, J.A., Sawicki, J., van Rooy, J. \& Smith, V.R. 2013b. New national and regional bryophyte records, 35. Journal of Bryology, 35(2): 129-39.

Ellis, L.T., Bakalin, V.A., Baisheva, E., Bednarek-Ochyra, H. Ochyra, R., Borovichev, E.A., Choi, S.S., Sun, B.-Y. Erzberger, P., Fedosov, V.E., Garilleti, R., Albertos, B. Górski, P., Hájková, P., Hodgetts, N.G., Ignatov, M., Koczur, A., Kurbatova, L.E., Lebouvier, M., Mežaka, A., Miravet, J., Pawlikowski, P., Porley, R.D., Rosselló, J.A., Sabovljević, M.S., Pantović, J., Sabovljević, A., Schröder, W. Ştefănuț, S., Suárez, G.M., Schiavone, M., Yayintaş, ÖT. \& Váňa, J. 2013c. New national and regional bryophyte records, 36. Journal of Bryology, 35(3): 228-38.

Ellis, L.T., Afonina, O.M., Asthana, A.K., Gupta, R., Sahu, V., Nath, V., Batan, N., Bednarek-Ochyra, H., Benitez, A. Erzberger, P., Fedosov, V.E., Górski, P., Gradstein, S.R. Gremmen, N., Hallingbäck, T., Hagström, M., Köckinger, H., Lebouvier, M., Meinunger, L., Németh, C., Nobis, M., Nowak, A., Özdemir, T., Pantović, J., Sabovljević, A. Sabovljević, M.S., Pawlikowski, P., Plášek, V., Cíhal, L., Sawicki, J., Sérgio, C., Ministro, P., Garcia, C.A. Smith, V.R., Ştefănuţ, S., Stow, S., Suárez, G.M. Flores, J.R., Thouvenot, L., Váňa, J., van Rooy, J. \& Zander, R.H. 2014a. New national and regional bryophyte records, 39. Journal of Bryology, 36(2): 134-51.

Ellis, L.T., Aleffi, M., Asthana, A.K., Srivastava, A., Bakalin, V.A., Batan, N., Özdemir, T., Bednarek-Ochyra, H., Borovichev, E.A. Brugués, M., Cano, M.J., Choi, S.S., De Beer, D., Eckstein, J., Erzberger, P., Fedosov, V.E., Ganeva, A., Natcheva, R. Garcia, C.A., Sérgio, C., Garilleti, R., Albertos, B., Puche, F. Gücel, S., Higuchi, M., Hugonnot, V., Hylander, K. Kırmacı, M., Aslan, G., Koponen, T., Lara, F., Mazimpaka, V. van Melick, H., Müller, F., Özenoglu Kiremit, H., Papp, B., Szurdoki, E., Plášek, V., Cíhal, L., van der Pluijm, A. Poponessi, S., Mariotti, M.G., Reyniers, J., Sabovljević, M.S. Sawicki, J., Smith, V.R., Stebel, A., Ştefănuț, S., Sun, B.-Y. Váňa, J. \& Venanzoni, R. 2014b. New national and regional bryophyte records, 40. Journal of Bryology, 36(3): 223-44.

Ellis, L.T., Aleffi, M., Tacchi, R., Alegro, A., Alonso, M., Asthana, A.K., Sahu, V., Biasuso, A.B., Callaghan, D.A., Ezer, T., Kara, R., Seyli, T., Garilleti, R., Gil-López, M.J., Gwynne-Evans, D., Hedderson, T.A., Kiebacher, T., Larrain, J., Long, D., Lüth, M., Malcolm, B., Mamontov, Y.S., Newsham, K.K., Nobis, M., Nowak, A., Ochyra, R., Pawlikowski, P., Plásěk, V., Cihal, L., Potemkin, A.D., Puche, F., Rios, D., Gallego, M.T. Guerra, J., Sawicki, J., Schäfer-Verwimp, A., SegarraMoragues, J.G., Šegota, V., Sofronova, E.V., Ștefănut, S., Szúcs, P., Bidló, A., Papp, B., Szurdoki, E., Tan, B.C. Vánă, J., Vigalondo, B., Draper, I., Lara, F., Yoon, Y.-J. Sun, B.-Y. \& Nishimura, N. 2014c. New national and regional bryophyte records, 41. Journal of Bryology, 36(4): 306-24

Ellis, L.T., Aleffi, M., Bakalin, V.A., Bednarek-Ochyra, H., Bergamini, A., Beveridge, P., Choi, S.S., Fedosov, V.E. Gabriel, R., Gallego, M.T., Grdović, S., Gupta, R., Nath, V. Asthana, A.K., Jennings, L., Kürschner, H., Lebouvier, M. Nair, M.C., Manjula, K.M., Rajesh, K.P., Nobis, M., Nowak, A., Park, S.J., Sun, B.-Y., Plášek, V., Č́íhal, L., Poponessi, S., Mariotti, M.G., Sabovljević, A., Sabovljević, M.S.,
Sawicki, J., Schnyder, N., Schumacker, R., Sim-Sim, M., Singh, D.K., Singh, D., Majumdar, S., Singh Deo, S., Stefănut, S., Suleiman, M., Seng, C.M., Chua, M.S., Váňa, J., Venanzoni, R., Bricchi, E. \& Wigginton, M.J. 2015a. New national and regional bryophyte records, 42. Journal of Bryology, 37(1): $68-85$.

Ellis, L.T., Asthana, A.K., Srivastava, A., Bakalin, V.A., BednarekOchyra, H., Cano, M.J., Jiménez, J.A., Alonso, M., Deme, J., Csiky, J., Dia, M.G., Campisi, P., Erzberger, P., Garilleti, R., Gorobets, K.V., Gremmen, N.J.M., Jimenez, M.S., Suárez, G.M., Jukonienè, I., Kiebacher, T., Kırmacı, M., Koczur, A., Kürschner, H., Lara, F., Mazimpaka, V., Larraín, J., Lebouvier, M., Medina, R., Natcheva, R., Newsham, K.K., Nobis, M., Nowak, A., Ören, M., Özçelik, A.D., Orgaz, J.D., Peralta, D.F., Plášek, V., Cíhal, L., Ristow, R., Sawicki, J., Schäfer-Verwimp, A., Smith, V.R., Stebel, A., Stefănut, S., Subkaitè, M., Sun, B.-Y., Uselienė, A., Uyar, G., Váňa, J., Yoon, Y.-J. \& Park, S.J. 2015b. New national and regional bryophyte records, 43. Journal of Bryology, 37(2): 128-46.

Frahm, J.-P. 1976. Zur Campylopus-Flora von Chile. Herzogia, 4: $141-60$

Frahm, J.-P. 1985. Afrikanische Campylopus-Arten (Dicranaceae, Musci). Bryophytorum Bibliotheca, 31: 1-216.

Frahm, J.-P. 1988. The subantarctic and southern hemispheric species of Campylopus (Dicranaceae), with contributions to the origin and speciation of the genus. Journal of the Hattori Botanical Laboratory, 64: 367-87.

Frey, W., Frahm, J.-P., Fischer, E. \& Lobin, W. 2006. The liverworts, mosses and ferns of Europe. Colchester: Harley Books. [English edn revised by T.L. Blockeel].

Frisvoll, A.A. 1978. The genus Tetraplodon in Norway. A taxonomic revision. Lindbergia, 4: 225-46.

Frisvoll, A.A. 1983. A taxonomic revision of the Racomitrium canescens group (Bryophyta, Grimmiales). Gunneria, 41: 1-181.

Gallego, M.T. 2005. A taxonomic study of the genus Syntrichia Brid. (Pottiaceae, Musci) in the Mediterranean region and Macaronesia. Journal of the Hattori Botanical Laboratory, 98: 47-122.

Gallego, M.T. 2006. Syntrichia (Pottiaceae). In: J. Guerra, M.J. Cano \& R.M. Ros, eds. Flora Briofitica Ibérica. Pottiales: Pottiaceae, Encalyptales: Encalyptaceae, Vol. III. Murcia: Universidad de Murcia, Sociedad Española de Briología. pp. 120-143.

Gallego, M.T., Guerra, J., Cano, M.J., Ros, R.M. \& SánchezMoya, M.C. 2000. The status and distribution of Syntrichia virescens var. minor (Pottiaceae, Musci). Bryologist, 103: 375-78

Gallego, M.T., Cano, M.J., Ros, R.M. \& Guerra, J. 2002. An overview of Syntrichia ruralis complex (Pottiaceae: Musci) in the Mediterranean region and neighbouring areas. Botanical Journal of the Linnean Society, 138: 209-24.

Gavin, D.G. 2009. The coastal-disjunct mesic flora in the inland Pacific Northwest of USA and Canada: refugia, dispersal and disequilibrium. Diversity and Distribution, 15(6): 972-82.

Greene, D.M. 1986. A conspectus of the mosses of Antarctica, South Georgia, the Falkland Islands and southern South America. Cambridge: British Antarctic Survey.

Gremmen, N.J.M. 1981. The vegetation of the subantarctic islands Marion and Prince Edward. The Hague: Junk Publishers.

Hodgetts, N.G. 2014. Checklist and country status of European bryophytes - towards a new Red List for Europe. Uppsala: Swedish Species Information Centre.

Hradílek, Z., Chlachula, J. \& Nesterova, S.G. 2011. New bryophyte records from Kazakhstan. Thaiszia Journal of Botany, 21: 29-36.

Husnot, T. 1884-1890. Muscologia Gallica. Descriptions et figures des mousses de France et des contrées voisines. Premiere partie - acrocarps Orne: T. Husnot. [Paris: F. Savy].

Ignatov, M.S. \& Lewinsky-Haapasaari, J. 1994. Bryophytes of Altai Mountains. II. The genera Amphidium Schimp., Orthotrichum Hedw. and Zygodon Hook. \& Tayl. (Orthotrichaceae, Musci). Arctoa, 3: 29-57.

Ignatov, M.S., Afonina, O.M. \& Ignatova, E.A. 2006. Checklist of mosses of East Europe and North Asia. Arctoa, 15: 1-130.

Ireland, R.R., Bellolio, B., Bednarek-Ochyra, H. \& Ochyra, R. 2005. Fertile plants of Racomitrium patagonicum (Bryopsida, Grimmiaceae). Journal of the Hattori Botanical Laboratory, 98: 203-09.

Johnson, F.D. \& Steele, R. 1978. New plant records for Idaho from Pacific coastal refugia. Northwest Science, 52(3): 205-11. 
Jovet-Ast, S. 1986. Les Riccia de la region Mediterraneenne. Cryptogamie. Bryologie-Lichénologie, 7(Suppl.): 287-431.

Jovet-Ast, S. 1991. Riccia (Hépatiques, Marchantiales) d Amerique Latine. Cryptogamie. Bryologie-Lichénologie, 12: 189-370.

Jovet-Ast, S. 2000. Documents pour la connaissance des Riccia Australiens (Hépatiques, Marchantiales) nouvelles récoltes. Taxons nouveaux. Commentaires morphologiques et écologiques. Cryptogamie, Bryologie, 21(4): 289-343.

Konstantinova, N.A. 2011. Contribution to the hepatic flora of the Republic of Dagestan (Eastern Caucasus, Russia). Arctoa, 20: 175-82.

Konstantinova, N.A., Akatova, T.V. \& Savchenko, A.N. 2009a Hepatics of the Caucasian state nature reserve (Western Caucasus, Russia). Arctoa, 18: 121-34.

Konstantinova, N.A., Bakalin, V.A., Andrejeva, E.N., Bezgodov, A.G., Borovichev, E.A., Dulin, M.V. \& Mamontov, Yu.S 2009b. Checklist of liverworts (Marchaniophyta) of Russia. Arctoa, 18: 1-63.

Kramer, W. 1980. Tortula Hedw. sect. Rurales De Not. (Pottiaceae, Musci) in der östlichen Holarktis. Bryophytorum Bibliotheca, 21: $1-165$.

Kürschner, H. 2000. Bryophyte flora of the Arabian Peninsula and Socotra. Bryophytorum Bibliotheca, 55: 1-131.

Kürschner, H. 2003. Nineteen new records to the bryophyte flora of Socotra Island. Additions to the bryophyte flora of the Arabian Peninsula and Socotra 5. Willdenowia, 33: 445-58.

Lara, F., Mazimpaka, V., Medina, R., Caparrós, R. \& Garilleti, R. 2010. Northeastern Turkey, an unnoticed but very important area for the Orthotrichaceae (Bryophyta). Nova Hedwigia, 138: 165-80.

Lazarenko, A.S. 1938. Materials on bryoflora of Middle Asia. Žurnal Instytuto Botaniky Vseukrajins'koji Akademijii Nauk, 26-67: 191-216. [in Russian].

Lewinsky-Haapasaari, J. 1994. Miscellaneous notes of Orthotrichum 5. Orthotrichum vicarium Laz. Lindbergia, 19: 37-9.

Liu, Y., Cao, T. \& Ge, X.-J. 2011. A case study of DNA barcoding in Chinese Grimmiaceae and a moss recorded in China for the first time. Taxon, 60(1): 185-93.

Malcolm, B. \& Shevock, J. 2012. Niphotrichum elongatum (Frisvoll) Bednarek-Ochyra \& Ochyra (Grimmiaceae) new to New Zealand and the Southern Hemisphere. Australasian Bryological Newsletter, 61: 13-4.

Mamatkulov, U.K., Baitulin, I.O. \& Nesterova, S.G. 1998 Bryophytes of Middle Asia and Kazakhstan. Almaty: MNAN. [in Russian].

Matteri, C.M. 1986. Los musci (Bryophyta) de las Islas Malvinas, su habitat y distribución. Nova Hedwigia, 43(1-2): 159-89.

Matteri, C.M. 2003. Los musgos (Bryophyta) de Argentina. Tropical Bryology, 24: 33-100.

Meinunger, L. \& Schröder, W. 2007. Verbreitungsatlas der Moose Deutschlands. Band 2. Regensburg: Herausgegeben von O. Dürhammer für die Regensburgische Botanische Gesellschaft.

Montagne, C. 1852. Note sur le Genre Riella et description d'une espece nouvelle $R$. reuteri. Annales des Sciences Naturelles Botanique, 3(18): 11-3.

Ochyra, R. 1985. Koponenia, a new pleurocarpous moss genus from Bolivia. Journal of Bryology, 13(4): 479-86.

Ochyra, R. 1987. On the taxonomy and family placement of the moss genus Limbella (C. Muell.) Broth. Journal of Bryology, 14(3): 465-85.

Ochyra, R. 1988. New taxa and new combinations of mosses proposed by Andrey S. Lazarenko. Journal of the Hattori Botanical Laboratory, 64: 335-46.

Ochyra, R. 2007. Grimmiaceae subfam. Racomitrioideae. In: Flor of North America Editorial Committee, eds. Flora of North America 27, Bryophytes: Mosses, part 1. New York: Oxford University Press. pp. 266-67.

Ochyra, R. \& Bednarek-Ochyra, H. 2007a. Bucklandiella. In: Flora of North America Editorial Committee, eds. Flora of North America 27, Bryophytes: Mosses, part 1. New York: Oxford University Press. pp. 267-85.

Ochyra, R. \& Bednarek-Ochyra, H. 2007b. Niphotrichum. In: Flora of North America Editorial Committee, eds. Flora of North America 27, Bryophytes: Mosses, part 1. New York: Oxford University Press. pp. 285-92.

Ochyra, R. \& Bednarek-Ochyra, H. 2011. Schistidium deguchianum (Grimmiaceae), a new Andean species from Peru. Journal of Bryology, 33(3): 189-94.

Ochyra, R. \& Bednarek-Ochyra, H. 2013. On the identity of Ditrichum validinervium (Bryophyta, Ditrichaceae). Cryptogamie, Bryologie, 34(3): 299-306.
Ochyra, R. \& Bednarek-Ochyra, H. 2014. Dicranella hookeri (Dicranaceae, Bryophyta) in northern Argentina. Telopea, 17: $331-35$.

Ochyra, R. \& Bednarek-Ochyra, H. 2015. Dicranoweisai fastigiata, a new synonym of Hymenoloma antarcticum (Seligeriaceae). Cryptogamie, Bryologie, 36(1): 41-5.

Ochyra, R. \& Broughton, D.A. 2004. Additions to the moss flora of the Falkland Islands. Journal of Bryology, 26(3): 232-36.

Ochyra, R. \& Hertel, H. 1990 [1991]. Contribution to the moss flora of the subantarctic island Marion. Polish Botanical Studies, 1: 19-34.

Ochyra, R. \& Lewis Smith, R.I. 1998. Antarctic species in the genus Ditrichum (Ditrichaceae, Bryopsida), with a description of D. gemmiferum sp. nov. Annales Botanici Fennici, 35(1): 33-53.

Ochyra, R., Sérgio, C. \& Schumacker, R. 1988. Racomitrium lamprocarpum (C. Muell.) Jaeg., an austral moss disjunct in Portugal, with taxonomic and phytogeographic notes. Bulletin $d u$ Jardin Botanique National de Belgique, 58: 225-58.

Ochyra, R., Bednarek-Ochyra, H., Pócs, T. \& Crosby, M.R. 1992 The moss Adelothecium bogotense in continental Africa, with a review of its world range. Bryologist, 95(3): 287-95.

Ochyra, R., Bednarek-Ochyra, H. \& Lewis Smith, R.I. 2002. New and rare moss species from subantarctic South Georgia. Nova Hedwigia, 74(1-2): 121-47.

Ochyra, R., Bednarek-Ochyra, H. \& Lewis Smith, R.I. 2008a. New and rare moss species from the Antarctic. Nova Hedwigia, 87(3-4): 457-77.

Ochyra, R., Lewis Smith, R.I. \& Bednarek-Ochyra, H. 2008b. The illustrated moss flora of Antarctica. Cambridge: Cambridge University Press.

Ochyra, R., Bednarek-Ochyra, H. \& van Rooy, J. 2013. Dicranella hookeri (Dicranaceae, Musci), an addition to the moss flora of continental Africa. Herzogia, 26(1): 169-74.

Otte, V. 2004. Flechten, Moose und lichenicole Pilze aus dem nordwestlichen Kaukasus - erster Nachtrag. Feddes Repertorium, 115(1-2): 155-63.

O'Shea, B.J. 2006. Checklist of the mosses of sub-Saharan Africa (version 5, 12/06). Tropical Bryology Research Reports, 6: $1-252$.

Papp, B., Dragićević, S. \& Erzbreger, P. 2014. Contribution to the bryophyte flora of Komovi Mts (Montenegro). Studia Botanica Hungarica, 45: 17-31.

Perold, S.M. 1991. A taxonomic revision of the Ricciaceae Reichenb. (Marchantiales: Hepaticae) in southern Africa. Dissertation. University of Pretoria Pretoria RSA. [PDF Accessed 1 January 2015].

Perold, S.M. 1999. Flora of Southern Africa. Hepatophyta. Part 1: Marchantiopsida. Fascicle 1: Marchantiidae. Pretoria: National Botanical Institute.

Perold, S.M. \& Volk, O.H. 1988. Studies in the genus Riccia (Marchantiales) from southern Africa. 8. R. campbelliana (subgenus Riccia) newly recorded for the region. Bothalia, 18: 37-42.

Philippe, M. 2013. Tetraplodon mnioides (Sw. ex Hedw.) Bruch et Schimp. (Splachnaceae) dans le massif du Jura. Archive for Bryology, 187: 1-6.

Porley, R.D. 2008. Threatened bryophytes: Leptodontium gemmascens. Field Bryology, 96: 14-25.

Porley, R.D. \& Edwards, S. 2010. Leptodontium proliferum Herzog (Bryopsida: Pottiaceae), new to Europe. Journal of Bryology, 32(1): 46-50.

Potemkin, A.D. 2001. Three new species of Scapania (Hepaticae) from India and China. Annales Botanici Fennici, 38: 83-9.

Rakhmatulina, E.K. 1970. Mosses of spruce forest of northern slope of Terskei Ala-Too. Flora Kyrgyzskoj SSR, Supplement 2.Frunze, pp. 50-59. [in Russian].

Rakhmatulina, E.K. 1990. Mosses of Herbarium of Institute of Biology of Academy of Science of Kyrgyz SSR. Izvestya Akademii Nauk Kyrgyzskoj SSR seriya Khimiko-technologicheskie $i$ biologicheskie nauki, 4: 48-56. [in Russian].

Ros, R.M., Mazimpaka, V., Abou-Salama, U., Aleffi, M., Blockeel, T.L., Brugués, M., Cano, M.J., Cros, R.M., Dia, M.G., Dirkse, G.M., El Saadawi, W., Erdağ, A., Ganeva, A., González-Mancebo, J.M., Herrnstadt, I., Khalil, K., Kürschner, H., Lanfranco, E., Losada-Lima, A., Refai, M.S., Rodríguez-Nuñez, S., Sabovljević, M., Sérgio, C., Shabbara, H., Sim-Sim, M. \& Söderström, L. 2007. Hepatics and Anthocerotes of the Mediterranean, an annotated checklist. Cryptogamie, Bryologie, 28(4): 351-437.

Ros, R.M., Mazimpaka, V., Abou-Salama, U., Aleffi, M., Blockeel, T.L., Brugués, M., Cros, R.M., Dia, M.G., Dirkse, G.M., Draper, I., 
El Saadawi, W., Erdag, A., Ganeva, A., Gabriel, R., GonzalezMancebo, J.M., Granger, C., Herrnstadt, I., Hugonnot, V., Khalil, K., Kürschner, H., Losada-Lima, A., Luis, L., Mifsud, S., Privitera, M., Puglisi, M., Sabovljević, M., Sérgio, C., Shabbara, H., Sim-Sim, M., Sotiaux, A., Tacchi, R., Vanderpoorten, A. \& Werner, O. 2013. Mosses of the Mediterranean, an annotated checklist. Cryptogamie, Bryologie, 34(2): 99-283.

Rothero, G. 2014. Tetraplodon angustatus. In: T. Blockeel, S.D.S. Bosanquet, M.O. Hill \& C.D. Preston, eds. Atlas of British and Irish Bryophytes. The distribution and habitat of mosses and liverworts in Britain and Ireland. Vol. 2. Newbury: British Bryological Society, Pisces Publications. pp. 251.

Sabovljević, M., Natcheva, R., Dihoru, G., Tsakiri, E., Dragičević, S., Erdağ, A. \& Papp, B. 2008. Check-list of mosses of SE Europe. Phytologia Balcanica, 14: 207-44.

Sawicki, J., Szczecińska, M., Bednarek-Ochyra, H. \& Ochyra, R. 2015. Mitochondrial phylogenomics supports splitting the traditionally conceived genus Racomitrium (Bryophyta: Grimmiaceae). Nova Hedwigia, 100(3-4): 293-317.

Schofield, W.B. 1980. Phytogeography of the mosses of North America (north of Mexico). In: R.J. Taylor \& A.E. Leviton, eds. The mosses of North America. San Francisco: Pacific Division of the American Association for the Advancement of Science. pp. 131-70.

Schuster, R.M. 1985. Austral Hepaticae. XIX. Some taxa new to New Zealand and New Caledonia. Phytologia, 56: 449-464.

Schuster, R.M. 1992. The Hepaticae and Anthocerotae of North America. Vol. 6, Chicago: Field Museum of Natural History.

Segarra-Moragues, J.G., Puche, F., Sabovljević, M., Infante, M. \& Heras, P. 2014. Taxonomic revision of Riella subgenus Trabutiella (Riellaceae, Sphaerocarpales). Phytotaxa, 159: 131-74.

Sérgio, C. 1992. Riccia macrocarpa Levier na Península Ibérica e Macaronésia. Estudo taxonómico, corológico e seu interesse fitogeográfico. In: Actes del Simposio Internacional de Botànica Pius Font $i$ Quer, Vol. I, Lleida, pp. 263-70.

Smith, A.J.E. 2004. The moss flora of Britain and Ireland (2nd edn). Cambridge: Cambridge University Press.

Söderström, L., Urmi, E. \& Váňa, J. 2002. Distribution of hepaticae and anthocerotae in Europe and Macaronesia. Lindbergia, 27: 3-47.

Stebel, A., Parusel, J.B. \& Cisło, G. 2004. Another locality for Tetrapodon angustatus (Bryopsida, Splachnaceae) in the Polish Carpathians. In: A. Stebel \& R. Ochyra, eds. Bryological studies in the Western Carpathians. Poznań: Sorus. pp. 75-8.
Ştefănuț, S. 2008. The hornwort and liverwort atlas of Romania. Bucureşti: Ars Docendi, Universitatea din Bucureşti.

Stefănuț, S. \& Goia, I. 2012. Checklist and red list of bryophytes of Romania. Nova Hedwigia, 95: 59-104.

Szmajda, P., Bednarek-Ochyra, H. \& Ochyra, R. 1991. M. 293 Tetraplodon angustatus (Hedw.) Bruch \& Schimp. In: R. Ochyra \& P. Szmajda, eds. Atlas of the geographical distribution of spore plants in Poland. Vol. 7. Kraków, Poznań: W. Szafer Institute of Botany of the Polish Academy of Sciences \& Adam Mickiewicz University. pp. 29-32.

Szweykowski, J., Buczkowska, K. \& Odrzykoski, I.J. 2005. Conocephalum salebrosum (Marchantiopsida). Plant Systematics and Evolution, 253: 133-58.

Vadam, J.-C. 1976. Une nouvelle station de Tetraplodon angustatus (Hedw.) B.e. Bulletin Société d'Histoire Naturelle du Pays de Montbéliard, 197(5-1976): 12-3.

Van der Putten, N., Verbruggen, C., Ochyra, R., Verleyen, E. \& Frenot, Y. 2010. Subantarctic flowering plants: pre-glacial survivors or post-glacial immigrants? Journal of Biogeography, 37(3): 582-92.

Venturi, G. 1887. Orthotrichum. In: T. Husnot, Muscologia Gallica. Prémiere partie - acrocarpes. Orne: T. Husnot. pp. 154-96.

Vitt, D.H., Marsh, J.E. \& Bovey, R.B. 1988. Mosses, lichens and ferns of northwest North America. Edmonton: Lone Pine Publishing.

Wheeler, J.A. 2000. Molecular phylogenetic reconstructions of the Marchantioid liverwort radiation. Bryologist, 103(2): 314-33.

Wigginton, M.J. 2004. Checklist and distribution of the liverworts and hornworts of sub-Saharan Africa, including the East African Islands (2nd edn). Tropical Bryology Research Reports, 5: $1-102$

Wilbraham, J. \& Matcham, H.W. 2010. Zygodon oeneus Herzog (Bryophyta: Orthotrichaceae) new to Uganda and Africa. Journal of Bryology, 32(3): 237-39.

Zander, R.H. 1972. Revision of the genus Leptodontium (Musci) in the New World. Bryologist, 75(3): 213-80.

Zander, R.H. 1994. Leptodontium. In: A.J. Sharp, H. Crum \& P.M. Eckel, eds. The moss flora of Mexico. Part one Sphagnales to Bryales. Bronx: Memoirs of the New York Botanical Garden. Vol 69, pp. 260-67.

Zanten, B.O. van. 1971. Musci. In: E.M. van Zinderen Bakker, Sr., J.M. Winterbottom \& R.A. Dyer, eds. Marion and Prince Edward Islands. Report on the South African Biological and Geological Expedition 1965-1966. Cape Town: A.A. Balkema. pp. 173-227.

\section{Molecular circumscription and intraspecific variation in Porella canariensis (F.Weber) Underw. (Porellaceae, Marchantiophyta)}

\section{Tina Lopes ${ }^{1,2}$, Michael Stech ${ }^{3,4}$, Susana Fontinha ${ }^{5}$, Manuela Sim-Sim ${ }^{1,2}$}

${ }^{1}$ Universidade de Lisboa, Faculdade de Ciências de Lisboa, DBV, Centro de Biologia Ambiental, Portugal, ${ }^{2}$ Museu Nacional de História Natural e da Ciência, Lisboa, Portugal, ${ }^{3}$ Naturalis Biodiversity Center, Leiden, The Netherlands, ${ }^{4}$ Leiden University, The Netherlands, ${ }^{5}$ ISOPlexis Universidade da Madeira/DSBIO-DRADR-SRA, Campus da Penteada, Portugal

The cosmopolitan genus Porella L. is the largest genus of Porellaceae with about 50-60 species (Schuster, 1980). Identification of Porella species can be difficult, due to high morphological plasticity

Correspondence to: T. Lopes, Museu Nacional de História Natural e da Ciência, Jardim Botânico/CBA, Rua da Escola Politécnica, no. 58, 1250102 Lisboa, Portugal. Email: tinalopes@cantab.net and lack of stable morphological characters, suggesting recent and still ongoing processes of speciation (Swails, 1970; Schuster, 1980).

Porella canariensis (F.Weber) Underw. occurs in Macaronesia (Azores, Madeira, Canary Islands, Cape Verde Islands) and the Iberian Peninsula (Fontinha, 2004; Ros et al., 2007; Casas et al., 2009). It is characterized by imbricate leaves with 